\title{
Review
}

\section{Selected Molecular Targets for Antiepileptogenesis}

\author{
Marek J. Pawlik ${ }^{1,+}{ }^{+}$, Barbara Miziak ${ }^{2,+}$, Aleksandra Walczak ${ }^{2}$, Agnieszka Konarzewska $^{2}$, \\ Magdalena Chrościńska-Krawczyk ${ }^{3}$, Jan Albrecht ${ }^{1, *, t, \neq} \neq$ and Stanisław J. Czuczwar ${ }^{2, *, t, \ddagger}$ \\ 1 Department of Neurotoxicology, Mossakowski Medical Research Institute, Polish Academy of Sciences, \\ 02-106 Warsaw, Poland; mpawlik@imdik.pan.pl \\ 2 Department of Pathophysiology, Medical University of Lublin, 20-090 Lublin, Poland; \\ barbaramiziak@umlub.pl (B.M.); aleksandrawalczakmd@gmail.com (A.W.); agnkonar@gmail.com (A.K.) \\ 3 Department of Child Neurology, Medical University of Lublin, 20-093 Lublin, Poland; madziachr@wp.pl \\ * Correspondence: jalbrecht@imdik.pan.pl (J.A.); stanislaw.czuczwar@umlub.pl (S.J.C.) \\ + These authors contributed equally. \\ $\ddagger$ Both authors share senior position.
}

check for updates

Citation: Pawlik, M.J.; Miziak, B.;

Walczak, A.; Konarzewska, A.;

Chrościńska-Krawczyk, M.; Albrecht,

J.; Czuczwar, S.J. Selected Molecular

Targets for Antiepileptogenesis. Int. J.

Mol. Sci. 2021, 22, 9737. https://

doi.org/10.3390/ijms22189737

Academic Editor: Fabio Altieri

Received: 5 August 2021

Accepted: 2 September 2021

Published: 8 September 2021

Publisher's Note: MDPI stays neutral with regard to jurisdictional claims in published maps and institutional affiliations.

Copyright: (c) 2021 by the authors. Licensee MDPI, Basel, Switzerland. This article is an open access article distributed under the terms and conditions of the Creative Commons Attribution (CC BY) license (https:/ / creativecommons.org/licenses/by/ $4.0 /)$.

\begin{abstract}
The term epileptogenesis defines the usually durable process of converting normal brain into an epileptic one. The resistance of a significant proportion of patients with epilepsy to the available pharmacotherapy prompted the concept of a causative treatment option consisting in stopping or modifying the progress of epileptogenesis. Most antiepileptic drugs possess only a weak or no antiepileptogenic potential at all, but a few of them appear promising in this regard; these include, for example, eslicarbazepine (a sodium and T-type channel blocker), lamotrigine (a sodium channel blocker and glutamate antagonist) or levetiracetam (a ligand of synaptic vehicle protein SV2A). Among the approved non-antiepileptic drugs, antiepileptogenic potential seems to reside in losartan (a blocker of angiotensin II type 1 receptors), biperiden (an antiparkinsonian drug), nonsteroidal anti-inflammatory drugs, antioxidative drugs and minocycline (a second-generation tetracycline with anti-inflammatory and antioxidant properties). Among other possible antiepileptogenic compounds, antisense nucleotides have been considered, among these an antagomir targeting microRNA-134. The drugs and agents mentioned above have been evaluated in post-status epilepticus models of epileptogenesis, so their preventive efficacy must be verified. Limited clinical data indicate that biperiden in patients with brain injuries is well-tolerated and seems to reduce the incidence of post-traumatic epilepsy. Exceptionally, in this regard, our own original data presented here point to c-Fos as an early seizure duration, but not seizure intensity-related, marker of early epileptogenesis. Further research of reliable markers of early epileptogenesis is definitely needed to improve the process of designing adequate antiepileptogenic therapies.
\end{abstract}

Keywords: epileptogenesis; antiepileptic drugs; losartan; nonsteroidal anti-inflammatory drugs; antioxidative drugs; antagomirs; c-Fos; epileptogenesis markers

\section{Introduction}

Antiepileptic drugs (AEDs; also named antiseizure drugs) efficiently control epileptic seizures in no more than ca. $65-70 \%$ of patients with epilepsy; this limitation holds for AEDs of the second and third generations as well, which substantiate a search for alternative treatment approaches [1]. Considering further that AEDs are only administered to patients with developed epilepsy, their antiepileptogenic potential has been a matter of dispute [2]

Epileptogenesis is a durable process that converts a normal mammalian brain into an epileptic one [3,4]. It therefore seems very likely that stopping or at least modifying the progress of epileptogenesis may eventually prevent the occurrence of epilepsy.

\section{Mechanisms of Epileptogenesis}

An initial insult, which may comprise status epilepticus, stroke or head trauma, is required to initiate epileptogenesis [3,4]. Interestingly, this process may persist after 
the onset of seizures and may negatively affect the seizure frequency [4]. Following the initial insult, two subsequent stages may be considered: (i) an acute one lasting from hours to weeks and encompassing neurodegeneration, elevated inflammatory activity and transcriptional events and (ii) a chronic one, taking even months, characterized by a sequence of events typically including neurogenesis, the sprouting of mossy fibers, reorganization of neuronal circuits and gliosis [5]. There is a correlation between mossy fiber sprouting (to the brain locations they never exist in) and the expression of seizure activity. Additionally, dentate granule cells present aberrant locations in the dentate gyrus (so-called ectopic granule cells), forming abnormal connections within the molecular layer of the dentate gyrus and in neurons located in the hippocampal CA3 field, which eventually results in the formation of excitatory circuits [6]. After all, gliosis may participate in the progress of epileptogenesis, as astrocytes may release a number of neurotransmitters and modulators, glutamate being the main excitatory neurotransmitter involved in the generation of epileptiform discharges [5]. In spite of the initial insult (for instance, acute seizure activity) that elevates the number of newborn neurons, neurogenesis within the hippocampus is decreased when chronic epilepsy develops. This is also often the case during epileptogenesis [5].

The stage of epileptogenesis has also been analyzed in terms of the expression of a number of genes. Interestingly, the genes responsible for the control of many signaling pathways undergo substantial alterations in their expression. For example, the genes for mTOR (mammalian target of rapamycin), insulin-like growth factor 1, transforming growth factor $\beta$, p38MAPK (p38 mitogen-activated protein kinases) and Jak-STAT (Janus kinases-signal transducer and activator of transcription proteins) may be given [6].

\section{AEDs-Do They Modify Epileptogenesis?}

AEDs have been in clinical use for decades, and their efficacy in inhibiting seizure activity in circa $65-70 \%$ of patients has been confirmed [7]. Notably, apart from patients surviving traumatic brain injury or stroke or those with initial febrile seizures, their probable antiepileptogenic potential in clinical conditions has not been studied. As for traumatic brain injury, the preventive use of carbamazepine, phenobarbital, phenytoin or valproate to stop the development of epilepsy has failed [8]. The same holds true for diazepam and phenobarbital in cases with febrile seizures and phenytoin or valproate in patients with brain tumors [8]. On the other hand, the prospects for their antiepileptogenic activity have been evaluated in a number of animal models-post-status epilepticus models induced by pilocarpine, kainate or electrical stimulations of discrete brain areas (for instance, the amygdala and hippocampus) seem to yield data possessing a predictive potential [9].

A fundamental question arises whether AEDs may be given to patients who are at risk of epilepsy, i.e., after status epilepticus [2] or brain infection [10]. A preventive treatment with AEDs could be implemented in vulnerable patients only, where markers of epileptogenesis tend to appear. This has been best illustrated in the case of EEG markers in epileptic seizures following cerebral malaria; around 10\% of children presenting the markers developed epilepsy [10].

The neuroprotective potential of AEDs against status epilepticus-induced brain damage in rodents has been widely documented (for review, Reference [2]). For instance, diazepam (in the low- and high-dose ranges), gabapentin, pregabalin, topiramate or valproate protected the vulnerable brain areas in animals that survived status epilepticus. There are also AEDs whose neuroprotective potential is not significant, and good examples are carbamazepine or phenytoin. As already stated above, neurodegeneration is encountered during the process of epileptogenesis, so the possibility exists that neuroprotective AEDs may at least reduce its intensity, which would eventually positively affect the frequency and intensity of seizures. In animal post-status epilepticus models, the best probable antiepileptogenic effect would be the total blockade of seizure activity following the silent period after status epilepticus. In control animals, distinct spontaneous seizure activity develops. AEDs were generally administered for a couple of days or weeks after status 
epilepticus-there are also examples of much longer AED administration (117 days for phenobarbital). The obtained results are mainly discouraging. Although valproate given at high daily doses for 40 days after kainate-induced status epilepticus in rats prevented hippocampal neurodegeneration and totally inhibited spontaneous seizures [2], the results obtained by other groups of investigators were the opposite. Following status epilepticus induced by pilocarpine in rats, valproate was given at $600 \mathrm{mg} / \mathrm{kg}$ daily for 3 weeks, and no neuroprotection or inhibition of spontaneous convulsions were recorded [2]. The results reported by a third group concerned status epilepticus produced by electrical stimulation of the basal amygdala in rats. Although valproate (at $600 \mathrm{mg} / \mathrm{kg}$ for 4 weeks) exerted clear-cut neuroprotection in the hippocampal area, no protection against spontaneous seizures was observed [2]. Some protective effects of gabapentin (a reduction of acquired epilepsy) or pregabalin (an extended latency to the onset of spontaneous convulsions) after chemically induced status epilepticus were noted [2]. Many conventional or newer AEDs were totally ineffective in this respect. Interestingly, diazepam at a high dose of $20 \mathrm{mg} / \mathrm{kg}$ administered as a single injection $2 \mathrm{~h}$ after status epilepticus evoked by electrical stimulation of the amygdala significantly reduced the number of rats exhibiting spontaneous convulsions [2]. Additionally, in the lithium-pilocarpine-induced status epilepticus in female rats, phenobarbital was administered i.p. for 2 weeks at $15 \mathrm{mg} / \mathrm{kg}$ twice daily, and then, the spontaneous seizure activity was studied for 7 days between 8 and 9 weeks after status epilepticus. Not only a reduction in the number of rats with spontaneous seizure activity was observed but the median frequency of convulsions sharply diminished from 7.5 to 1 seizure per week [11]. Another positive example might be levetiracetam (a ligand of synaptic vehicle protein SV2A [2]), however, when administered at a very high dose of $500 \mathrm{mg} / \mathrm{kg}$ (p.o. twice daily) for 4 weeks in mice after pilocarpine-produced status epilepticus [12]. The seizure activity was assessed in the presence of levetiracetam within four weeks after status epilepticus. In these circumstances, levetiracetam effectively reduced the number of spontaneous seizures, mortality and exerted neuroprotective effects [12].

Although voltage-operated sodium channel inhibitors (carbamazepine and phenytoin) seem ineffective in terms of epileptogenesis (for review, Reference [2]), a third-generation AED, eslicarbazepine, apart from the sodium channel blockade is also an effective blocker of T-type voltage-dependent calcium channels [13]. Interestingly, this drug proved an efficient inhibitor of epileptogenesis in the pilocarpine model of status epilepticus in mice. The drug was given i.p. at 150 and $300 \mathrm{mg} / \mathrm{kg}$ once daily for 6 weeks. Eventually, the spontaneous seizure activity was significantly reduced when evaluated 8 weeks after the status and the mossy fiber sprouting was considerably inhibited [14]. Thus, as a target for antiepileptogenesis, T-type voltage-dependent calcium channels could be considered. The beneficial effects of eslicarbazepine in this respect seem to support this assumption [14]. However, more preclinical studies are required on this issue. Remarkably, one other Ttype calcium channel inhibitor, ethosuximide [13] at 25 and $50 \mathrm{mg} / \mathrm{kg}$, was in the same experimental approach devoid of an antiepileptogenic activity (see below, Reference [14]).

Lamotrigine is a relatively new AED blocking voltage-operated sodium channels [13]. There are also data available suggesting the blockade of AMPA glutamate receptors at pharmacologically relevant concentrations [15], although recent data by Fukushima et al. [16] pointed to a blockade of NMDA glutamate receptors. When given i.p. $24 \mathrm{~h}$ after lithiumpilocarpine status epilepticus in rats at 10 or $20 \mathrm{mg} / \mathrm{kg}$ daily for one week, lamotrigine very distinctly inhibited the post-status epilepticus spontaneous seizure activity evaluated in weeks 5 and 6 . In the hippocampus, neurodegeneration and astrogliosis were reduced by a lamotrigine pretreatment [17]. Ethosuximide (a T-type calcium channel blocker [13]) at 25 and $50 \mathrm{mg} / \mathrm{kg}$ in the same experimental conditions proved completely ineffective [17]. 


\section{Approved Non-AEDs with an Antiepileptogenic Potential}

Employing approved non-AEDs, showing a potent antiepileptogenic potency, would reduce the time necessary for implementing a novel antiepileptogenic drug compared to completely new compounds, requiring full approval procedures. No doubt, such drugs are available, and losartan seems a very promising one. Interestingly, this antihypertensive drug (a blocker of angiotensin II type 1 receptors) was evaluated in a rat model of acquired epilepsy in which sodium deoxycholate, via a craniotomy window, was administered to the brain surface. This procedure resulted in an extravasation of albumins into the brain due to vascular injury [18]. The extravasation of albumin complexes into the brain tissue may be encountered in a stroke, head trauma or infection [19-21]. This process is responsible for neuroinflammation involving TGF- $\beta$ signaling and subsequent epileptiform activity [22]. Losartan at 100-mg/kg i.p. was administered $40 \mathrm{~min}$ following deoxycholate, and its relevant plasma concentration was maintained through drinking water $(2 \mathrm{~g} / \mathrm{L})$ for 3 weeks. The spontaneous seizure activity was evaluated for 2 weeks, starting from the 7th day after losartan was stopped. It turned out that the losartan treatment effectively affected epileptogenesis, which was reflected by a significant reduction of rats exhibiting spontaneous convulsions. While all control rats presented clear-cut seizure activity, $60 \%$ of the animals receiving losartan were seizure-free. A sharp reduction in the average number of convulsions was also recorded, with 8 /week in the control group vs. 2.25 /week in the losartan group [18]. The authors carried out an additional experiment in the absence of blood-brain barrier damage. Toward this aim, they perfused albumin over the brain tissue and started to record the electrocorticographic activity for 110 days. At least two spontaneous seizures (appearing 2 days after albumin exposure) were noted in $85 \%$ of rats, and the average number of seizures reached 6.08 per week. In contrast, the proportion of seizing rats in the group perfused with albumin + losartan was reduced to $25 \%$, the average number of seizures being 0.23 seizures/week.

The antiepileptogenic activity of losartan was also reported in the kainate post-status epilepticus-induced epileptogenesis model in rats [23]. The angiotensin receptor 1 blocker was initiated s.c. at $10 \mathrm{mg} / \mathrm{kg} 2 \mathrm{~h}$ after the onset of status epilepticus and continued up to the 3rd day, and then, the animals were switched to losartan in drinking water up to 4 weeks. Spontaneous seizure activity was evaluated for 3 months. Apart from seizures, possible behavioral deficits and hippocampal neurodegeneration were also taken into consideration. Evidently, a pretreatment with losartan increased the latency of the onset of seizures and provided distinct neuroprotection to the CA1 hippocampal subfield. In other hippocampal regions, neuroprotection was also observed, although less expressed. Importantly, in a number of behavioral tests, losartan pretreated rats exhibited considerably less deficits [23]. When losartan was evaluated in an identical experimental approach in spontaneously hypertensive rats, the only difference observed was associated with the behavioral deficits not affected by the losartan pretreatment [24]. Some antiepileptogenic activity of losartan was confirmed in amygdala-kindled rats, because this antihypertensive drug extended the latency time of the development of fully kindled seizures [25]. The drug was either administered i.c.v. or peripherally and significantly elevated the number of stimulations needed to obtain fully kindled rats. After all, no damage to the blood/brain barrier was observed in these animals. However, some seizure parameters (threshold for after discharge induction, after discharge duration or seizure severity in fully kindled animals) were not modified by losartan pretreatment [25].

Rapamycin (an immunosuppressant drug) has been documented to block mTOR complex 1 (mammalian target of rapamycin), which is a serine/threonine protein kinase responsible for neuronal protein synthesis [26]. This drug has been tested for its potential antiepileptogenic properties in rats subjected to status epilepticus induced by kainate at $10 \mathrm{mg} / \mathrm{kg}$ [27]. In rats given rapamycin at $6 \mathrm{mg} / \mathrm{kg}$ every 4 days, a considerable reduction in the number of spontaneous convulsions was evident on days 17 and 21 after status epilepticus. Following status epilepticus produced by the electrical stimulation of the rat angular bundle, rapamycin $(6 \mathrm{mg} / \mathrm{kg}$ daily for a week and then every other day for 6 weeks 
following status epilepticus) totally inhibited the occurrence of spontaneous seizure activity in $25 \%$ of the animals. In the remaining $75 \%$, a significant reduction of seizure activity was shown [28]. This antiepileptogenic activity of rapamycin was associated with its neuroprotective effect in the hippocampus and a reduction in the increased permeability of the blood/brain barrier. Nevertheless, inflammation markers in the hippocampus were not affected by the pretreatment with rapamycin [28]. However, there are also data available on the lack of antiepileptogenic activity of this mTOR blocker. After $24 \mathrm{~h}$ following pilocarpineinduced status epilepticus in mice, the rapamycin administration $(10 \mathrm{mg} / \mathrm{kg})$ was started and continued up to 2 months. The monitoring of spontaneous motor seizures began 1 month after status epilepticus and was carried out for a month, and after 2 months, mossy fiber sprouting was evaluated. Whilst mossy fiber sprouting and dentate gyrus hypertrophy were suppressed in mice receiving rapamycin, no difference in the seizure frequency was found. Additionally, the loss of hilar neurons was not prevented. The seizure frequency reached 0.137 seizures per hour in the control group and 0.133 seizures per hour in the rapamycin group. There was a large number of subjects in both groups $(\mathrm{N}=64)$ [29]. In a very similar experimental approach, rapamycin was given in a lower dose of $3 \mathrm{mg} / \mathrm{kg}$ in mice [30]. No effect of rapamycin on the spontaneous seizure frequency was noted, however, mossy fiber sprouting was reduced by $42 \%$ and the hypertrophy of the dentate gyrus was decreased compared with the control group. Nevertheless, in rapamycin-treated mice, the generation of ectopic granule cells, loss of hilar neurons or granule cell proliferation were still observed [30].

Potential antiepileptogenic agents may be searched for among nonsteroidal antiinflammatory drugs affecting diverse inflammatory pathways. A good example is celecoxib, blocking the cyclooxygenase 2 and HMGB1/TLR-4 pathways, which was evaluated in rats surviving lithium-pilocarpine status epilepticus [31]. The drug was started at $20 \mathrm{mg} / \mathrm{kg}$ p.o. one day after status epilepticus and stopped at day 28th, thus covering the latent period. The parameters of spontaneous convulsions (frequency and duration observed between 28 and 42 days) were considerably reduced by the celecoxib pretreatment. Concomitantly, a potent neuroprotection was observed in the hippocampus with aberrant neurogenesis/gliogenesis being significantly decreased [31].

$\mathrm{N}$-acetylcysteine is a drug approved by the FDA for the management of liver toxicity resulting from an overdose of acetaminophen, and it may also be applied as an agent loosening the thick mucus encountered in patients with chronic obstructive lung diseases [32]. The main antioxidant activity of this drug is due to its chemical structure of a reduced glutathione precursor [32]. When given an i.v. dose of $30 \mathrm{mg} / \mathrm{kg}$ immediately after systemic kainate-induced status epilepticus in rats, an increased seizure threshold of flurothyl ether was noted 12 weeks later, and mossy fiber sprouting was inhibited [33]. In another experiment, $\mathrm{N}$-acetylcysteine was supplemented at $100 \mathrm{mg} / \mathrm{kg}$ p.o. for 5 weeks following brain trauma induced in rats by fluid percussion injury. Rats supplemented with the antioxidant did not react to the subthreshold dose of pentylenetetrazol (30 mg/kg i.p.), which, in control rats, induced generalized tonic-clonic seizures. Moreover, the latency of the first myoclonic jerk was considerably reduced in the vehicle-treated group, whilst the pretreatment with $\mathrm{N}$-acetylcysteine brought it back to the control value of the rats without brain injury [34].

Minocycline (a second-generation tetracycline with anti-inflammatory and antioxidant properties [35]) was shown to possess some antiepileptogenic potential in lithiumpilocarpine-induced status epilepticus in rats. The authors of this study [36] provided evidence that the status epilepticus produced a prolonged activation of both astrocytes and microglia. Minocycline was given at $45 \mathrm{mg} / \mathrm{kg}$ for 2 weeks after the status epilepticus. Then, after a period of 6 weeks after minocycline was withdrawn, spontaneous recurrent convulsions were monitored for 2 weeks. The seizure activity was considerably suppressed in minocycline-pretreated animals in terms of its frequency, severity and duration. Further, this drug also mitigated the activation of microglia and reduced the elevated production of tumor necrosis factor- $\alpha$ and interleukin- $1 \beta$ in the hippocampal 
CA1 subfield and the neighboring cortex. However, the activation of astrocytes was not affected by the minocycline pretreatment [36]. When the status epilepticus was induced electrically in rats, minocycline failed to modify the spontaneous recurrent seizures [37]. Nevertheless, the pretreatment with this drug abolished the spatial memory deficit and normalized locomotion. No anti-inflammatory effects of minocycline were shown [37].

\section{Combined Treatments}

Considering a number of diverse mechanisms present during epileptogenesis, some authors have represented the point of view that combinations of drugs or agents sharing complementary mechanisms might be especially useful in this regard. The first attempt assumed there were beneficial effects of two combinations with AEDs, i.e., levetiracetam + topiramate and levetiracetam + phenobarbital, in mice after intrahippocampal kainate [38]. The former combination of levetiracetam $(200 \mathrm{mg} / \mathrm{kg}$ i.p.) and topiramate (30 mg/kg i.p.) was given for 5 days (latent period), starting after $6 \mathrm{~h}$ from the status induction. Video/EEG monitoring for 1 week was brought about 4 and 12 weeks after intrahippocampal kainate. Brain histology was evaluated 6 and 12 weeks later. The authors distinguished electrographic seizures (observed in the EEG) and electroclinical seizures (recorded both in the EEG and videos), the former being more frequent. The combined treatment was very effective in that it reduced the frequency of spontaneous recurrent electroclinical seizures by $80 \%$ when compared to nontreated mice. The number of animals with spontaneous electroclinical convulsions was also diminished, indicating that some mice were completely protected. Moreover, the severity of the electroclinical convulsions was distinctly reduced, as manifested by less-generalized seizures (stages 4 and 5 according to a Racine scale). However, the electrographic seizure activity was not affected by the combined treatment. Moreover, no effects on the neurodegeneration or inflammatory reactions were found. The second drug combination (phenobarbital, initiated by a bolus dose of $25 \mathrm{mg} / \mathrm{kg}$ and then 3 times daily at $15 \mathrm{mg} / \mathrm{kg}$ i.p.) + levetiracetam (other details of the experiment identical to the first combination) did not modify any parameter evaluated in this study [38]. In the same model of status epilepticus in mice, a number of combinations, consisting of two to four different drugs, was evaluated in a comparable experimental approach [39]. The most beneficial combination of levetiracetam $(60 \mathrm{mg} / \mathrm{kg}$ i.p.) + atorvastatin $(3 \mathrm{mg} / \mathrm{kg}$ i.p. $)+$ ceftriaxone $(60 \mathrm{mg} / \mathrm{kg}$ i.p.) inhibited not only the incidence of electroclinical seizures (by 100\%) but the incidence of electrographic seizures (by $60 \%$ ) as well. Hippocampal neurodegeneration was not affected [39].

\section{Antioxidative Dietary Supplements}

Resveratrol (a natural phytoalexin polyphenol that may be extracted from grapes and other food products) possesses a strong antioxidative potential [40]. Apart from its antioxidative properties, the compound also exhibits anti-inflammatory and anticarcinogenic activities [41]. These mechanisms of action may be quite encouraging in terms of epileptogenesis inhibition, considering that not only inflammatory processes but also oxidative stress may be involved in this process [40]. Indeed, resveratrol proved effective in inhibiting spontaneous seizures after intrahippocampal kainate-induced status epilepticus in rats [42]. Whilst, in the control group, $75 \%(N=12)$ of the rats exhibited seizure activity, only $14.3 \%(N=7)$ did so in the resveratrol group. Additionally, in the latter group, a considerable reduction in the number of spontaneous recurrent seizures was shown. As regards the histological evaluation, the resveratrol group presented neuroprotection in some hippocampal areas (CA1 and CA3a), and mossy fiber sprouting was distinctly inhibited [42]. This antioxidative compound also extended the seizure latency and reduced the seizure score in pentylenetetrazol-kindled convulsions in rats, along with the neuroprotection and inhibition of oxidative stress induced by seizure activity [43].

Another compound, curcumin (an active component of turmeric), has been documented in vitro to possess, apart from an antioxidant activity, anti-inflammatory and neuroprotective properties [44]. Interestingly, the in vitro activity was not confirmed in the 
hippocampal tissue one week after status epilepticus in the post-electrical rat model for temporal lobe epilepsy [44]. Nevertheless, when applied during the silent period to rats following kainate-induced status epilepticus, while it did not prevent the development, it did reduce the severity of the subsequent spontaneous convulsions and offered a significant protection against cognitive impairment [45].

Bioactive phytochemical sulforaphane (available in broccoli sprout supplements) is an activator of the transcription factor (nuclear factor erythroid 2-related factor 2; Nrf2) responsible for the stimulation of various cellular defense lines through a number of cytoprotective genes [46]. Pauletti et al. [47] induced status epilepticus in rats via the electrical stimulation of the ventral hippocampus and then applied a combination of sulforaphane ( $5 \mathrm{mg} / \mathrm{kg}$ i.p.) with $\mathrm{N}$-acetylcysteine $(500 \mathrm{mg} / \mathrm{kg}$ i.p.) for seven days, followed by sulforaphane alone for another 7 days. Evidently, the combined treatment effectively inhibited the epileptogenesis progression as measured between 2 and 5 months, which was reflected by a significant reduction in the frequency of spontaneous seizures evaluated 5 months after the status epilepticus. Moreover, in rats receiving both antioxidants, the hippocampal neurodegeneration was considerably less expressed, and they performed better in behavioral tests for cognition. Last, but not least, oxidative stress accompanying epileptogenesis led to an expression of a neuroinflammatory molecule, the so-called high mobility group box 1 (HMBG1). A reduced post-status epilepticus oxidative stress by the two antioxidants significantly prevented the generation of HMBG1, which could be involved in the beneficial effects of the combination [47].

\section{Examples of New, As-Yet Nonapproved Compounds with Antiepileptogenic Potential}

As already mentioned above, rapamycin is an antagonist of the mTOR complex 1 pathway, so a question arises whether a blockade of two mTOR pathways may offer a more efficient inhibition of epileptogenesis. Towards this aim, a 1,3,5-triazine derivative (PQR620) was evaluated in mice surviving status epilepticus induced by intrahippocampal kainate [48]. PQR620 was given for 2 weeks (at doses blocking the mTOR signaling), and the seizure evaluation began 6 weeks after the drug administration was stopped. Surprisingly, no protective effect of the pretreatment with this compound on the spontaneous seizure incidence or frequency was observed. Additionally, no desired influence on granule cell dispersion in the dentate gyrus was recorded. A significant anxiety reduction was the only behavioral response seen in pretreated mice. In the same experimental approach, another triazine derivative, PQR530 (an inhibitor of the phosphoinositide-3 kinase (PI3K)AKT/mTOR pathway), exerted an activity similar to PQR620 [48].

Z-944, a selective and potent antagonist of the T-type calcium channel, has been examined in rats with kainate-induced status epilepticus and subsequent epileptogenesis [49]. Z944 was administered via a continuous subcutaneous infusion at $60 \mathrm{mg} / \mathrm{kg}$ daily for 4 weeks. After a 4-week interval, the animals were tested for the occurrence of spontaneous recurrent convulsions for the next 2 weeks and behavioral abnormalities (anxiety, depression and cognition). Apparently, the group receiving the calcium channel antagonist showed less intense seizure activity manifested by a reduced number of convulsions -0.8 seizures per day (vehicle-treated rats) vs. 0.01 seizures daily. Additionally, vehicle-treated rats exhibited significant deficits in spatial learning and memory tasks, as well as distinct depressive-like behavior vs. animals without status epilepticus. The pretreatment with Z944 considerably prevented the occurrence of abnormal behaviors [49].

A very intriguing hypothesis regarding the role of DNA methylation was put forward by Williams-Karnesky et al. [50], who administered adenosine at $250 \mathrm{ng}$ daily (for 10 days) through silk-based polymer implants into rat brain ventricles. The administration of adenosine started 9 weeks following systemic kainate $(12 \mathrm{mg} / \mathrm{kg}$, i.p.)-induced status epilepticus. Spontaneous seizures were evaluated between 10-13 and 18-21 weeks since the induction of status epilepticus. Adenosine very potently inhibited the increase in seizure frequency per week between 10 and 13 weeks and completely blocked any further increases in this parameter when evaluated between 18 and 21 weeks. Moreover, mossy 
fiber sprouting was significantly reduced when studied 12 weeks post-status epilepticus. According to the authors, the observed seizure-modifying effect was distinctly correlated with the inhibition of hippocampal DNA methylation [50].

Very promising effects were reported with the use of an antagomir (an antisense oligonucleotide) that targets microRNA-134 (ANT-134). Experiments were performed on the mice that survived intra-amygdalar kainate-induced status epilepticus. ANT$134(30 \mathrm{mg} / \mathrm{kg})$ was administered i.p. $2 \mathrm{~h}$ after the induction of status epilepticus, and EEG/spontaneous recurrent convulsions were recorded for 2 weeks and for 1 week after 1,2 and 3 months following the status epilepticus. Evidently, spontaneous seizures were almost totally blocked by a single injection of ANT-134. Additionally, a reduced astrogliosis was found in the hippocampus [51].

Brain-derived neurotrophic factor (BDNF) is a neurotrophin involved in the modulation of synaptic plasticity and may be engaged in various functions of the central nervous system-for instance, memory processes [52]. Seizure activity is responsible for the enhanced activation of the BDNF receptor, which is tropomyosin-related kinase B (TrkB), coupled to phospholipase-C-gamma-1 [53,54]. Consequently, there is a possibility that the inhibition of TrkB signaling might be of importance in the suppression of epileptogenesis. A combined chemical-genetic approach was elaborated in order to inhibit TrkB. In wild-type mice, the enzyme is not susceptible to 1-(1,1-dimethylethyl)-3-(1-naphthalenylmethyl)-1Hpyrazolo[3,4-d]pyrimidin-4-amine (1NMPP1). However, 1NMPP1 turns into an active inhibitor after a genetic modification in the TrkB locus, which consists of the substitution of alanine for phenylalanine at residue 616. The inhibitory activity of 1NMMP1 was subsequently validated in vivo in the genetically modified mice [54]. The inhibitor was given i.p. at $16.6 \mu \mathrm{g} / \mathrm{g} 40$ and $60 \mathrm{~min}$ after intra-amygdalar kainate (with diazepam at $10 \mathrm{mg} / \mathrm{kg}$ and lorazepam at $6 \mathrm{mg} / \mathrm{kg}$, respectively, to terminate the status epilepticus) and then once daily. Additionally, it was available in the drinking water (at $25 \mu \mathrm{M}$ ). After 2 weeks, 1NMMP1 was withdrawn. Spontaneous seizures were measured daily in weeks 5 and 6 and behavioral testing after 8 weeks post-status epilepticus. There was a sharp reduction in the occurrence of spontaneous seizure activity in the long-term period after status epilepticus. Anxiety-like behavior was also ameliorated by the pretreatment with 1NMMP1 in genetically modified mice in the light-dark emergence test. As expected, 1NMMP1 remained ineffective in unmodified animals [54].

A similar experimental approach was used in amygdala-kindled genetically modified mice [55]. Amygdala-kindled mice (genetically modified as in the former experiment) after 6 days of a seizure-free period received an electrical stimulus inducing a seizure response (Seizure \#1) and then, after 8 days, a second stimulus (Seizure \#2), showing a significant progression in the seizure duration. The treatment with 1NMMP1 $(16.6 \mu \mathrm{g} / \mathrm{g})$ was administered i.p. after Seizure \#1 every $12 \mathrm{~h}$ up to a total of five injections, and the mice also had access to drinking water with the TrkB inhibitor (at $25 \mu \mathrm{M})$ for 2 days. It turned out that, in the genetically modified mice receiving 1NMMP1, there was a clear-cut prevention of a $50 \%$ increase in the electrographic seizure duration and a $25 \%$ increase in the behavioral seizure duration, as well as a $75 \%$ increase in the duration of the ictal and postictal events. These beneficial events were not seen in the modified mice injected with the 1NMMP1 vehicle or in naïve mice administered the TrkB inhibitor itself. There is also a possibility of inhibiting TrkB signaling by the peptide pY816, uncoupling TrkB from phospholipaseC-gamma-1. Indeed, when applied after Seizure \#1 at $20 \mathrm{mg} / \mathrm{kg}$ i.p. for a total of five injections in naïve amygdala-kindled mice, it very significantly prevented an increase of the seizure parameters after the induction of Seizure \#2. Remarkably, carbamazepine (a conventional AED) given i.p. at $20 \mathrm{mg} / \mathrm{kg}$ every $4 \mathrm{~h}$ for 2 days after Seizure \#1 totally failed to modify the progression of seizure activity observed at Seizure \#2 [55]. 


\section{8. c-Fos: A Potential Target for Antiepileptic Treatment}

The stimulation of neurons by a variety of factors activates a group of immediate early genes (IEG), of which c-fos coding for the 37.5-kDa protein c-Fos is the one responding most rapidly [56,57]. Accordingly, epileptic seizures induced in experimental animals by electrical stimulation (electroconvulsive seizures, (ECS) [58,59]), or by a variety of chemicals (kainate, pilocarpine or pentylenetetrazol), are invariably accompanied by a rapid increase in the expression of c-Fos mRNA and/or proteins in the neurons of seizure-vulnerable brain regions (within minutes to a few hours following the induction of the first seizure) [60-66]. c-Fos activation is transient, very often receding in the latent, asymptomatic stage of epilepsy, way before the onset of recurrent seizures. Notably, in rats subjected to acute ECS, the increase of c-Fos is followed by a decrease to below the control level in the period when seizures become chronic [58]. Rapid but transient c-Fos induction has also been observed in human temporal lobe slices obtained from the surgical treatment of TLE following their epileptogenic stimulation in vitro [67].

We attempted to evaluate the so-far never analyzed relation of c-Fos expression to two characteristics of initial seizures: (i) the time lapse between the stimulus application and the onset of the first seizure and (ii) seizure intensity as measured with the Racine score. In this laboratory, each of the two parameters and their correlation with glutamatergic transmission were investigated in the lithium-pilocarpine model in young rats, until $60 \mathrm{~min}$ after the stimulus application in a minute timescale [68]. The study revealed considerable animal-to-animal variations with regards to parameters (i) and (ii). The variability was further accentuated in a separate group of animals treated with a seizure onset-delaying glutamatergic intervener, MSO. An analysis of the brain tissue samples derived from lithium-pilocarpine animals revealed in both the MSO-treated and nontreated group a strong negative correlation of c-Fos mRNA expression with a timelapse from the pilocarpine application to the onset of the first generalized seizure but no statistically significant correlation with the seizure intensity (Figure 1). The results suggested that, the longer the animal remains resistant to the seizure-inducing stimulus, the lesser will its c-Fos response. To express this another way, the longer the animal suffers from seizures, the higher its brain c-Fos expression.

While the above observations strongly support the status of c-Fos as an early, seizure duration-related marker of epileptogenesis, they leave open the question of the contribution of c-Fos to epileptogenesis and, thus, of its assignment to the list of therapeutic targets. Since c-Fos positively regulates several aspects of neural plasticity [68], its activation in the initial stages of epileptogenesis may be considered as a neuroprotective response. Some experimental data appear to support this view. The increase of c-Fos expression elicited by trigeminal nerve stimulation coincided with, and likely contributed to, the attenuation of pentylenetetrazol-induced seizures in rats [70]. Other than in epilepsy-prone Wistar rats, in Guyenne spiny rats (Proechimys guyannensis), pilocarpine-induced seizures never evolve to status epilepticus; the unusual epilepsy resistance of this species is correlated with a persistent high level of c-Fos expression after the ictal stimulus [71]. However, the transient activation of c-Fos may, in most instances, be too short-lasting to mitigate a palpable degree of progression of epileptogenesis to chronic epilepsy. A c-Fos deficit at later stages of epileptogenesis could contribute to impaired cognition and memory, the well-documented associates of advanced epilepsy [72,73]. 


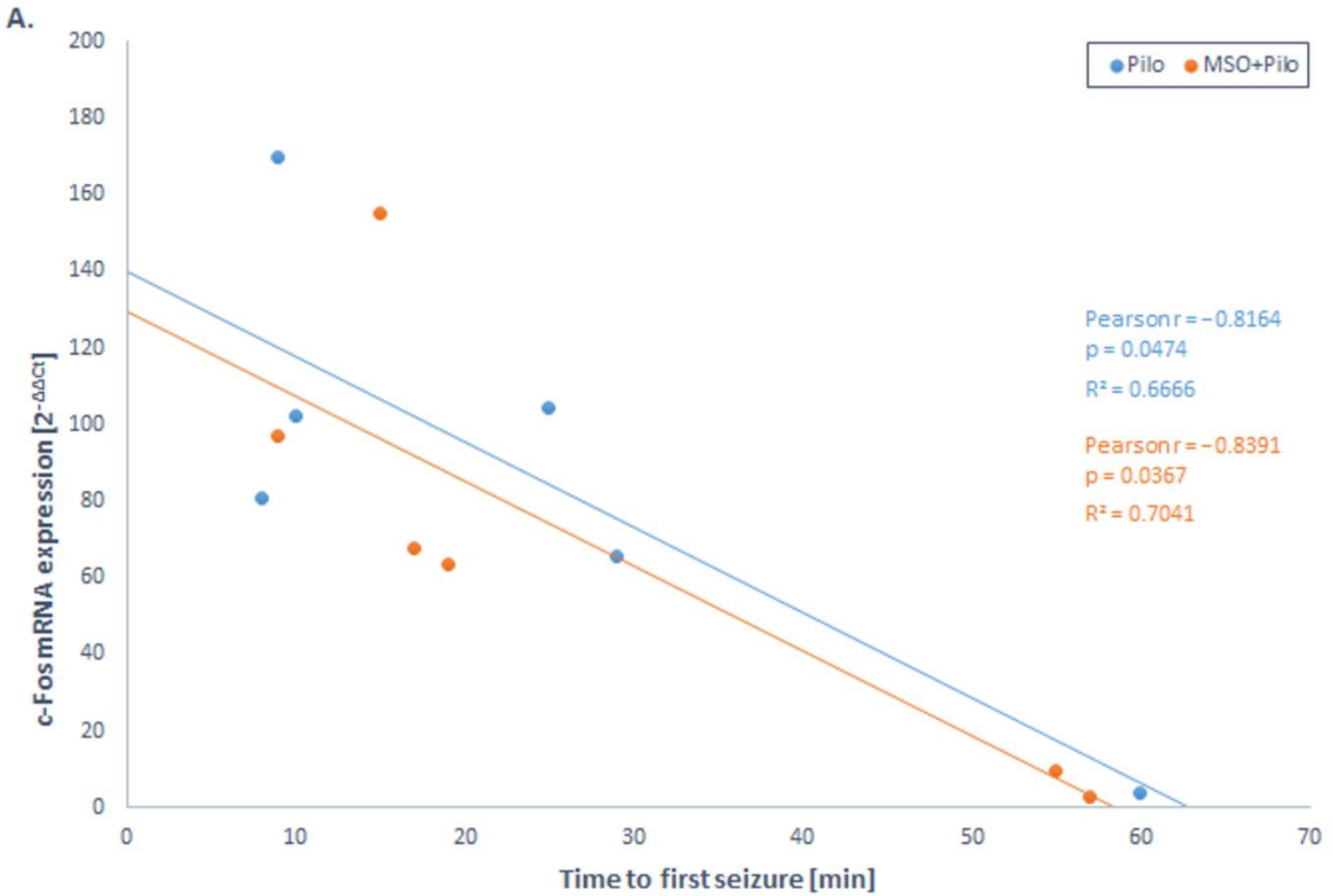

B.

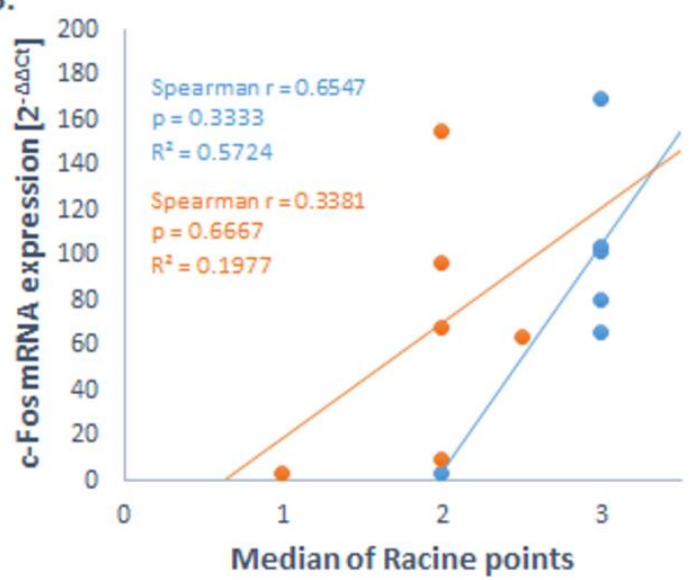

c.

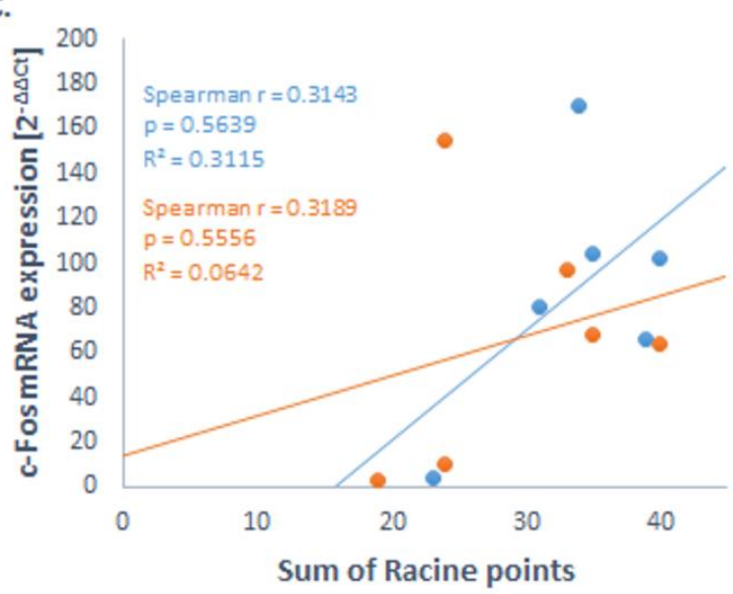

Figure 1. C-Fos mRNA expression in the hippocampus vs. time to the onset of the first generalized seizure (A) and the seizure intensity: median of the Racine points $(\mathbf{B})$ and sum of the Racine points $(\mathbf{C})$. Rats received one dose of glutamine synthetase inhibitor MSO (MSO + Pilo group, $N=6$ ) or an equal volume of saline (Pilo group, $N=6$ ) $2.5 \mathrm{~h}$ before the convulsive agent-pilocarpine. (A) Point 0 is the time of pilocarpine application. Assessment of the Racine score was made every $5 \mathrm{~min}$ up to $60 \mathrm{~min}$ after pilocarpine, when the animals were decapitated, and the brain tissue was dissected. A correlation coefficient was considered statistically significant at the two-tailed $p$-value $<0.05$. For a more detailed description of the model used, see Reference [68]. The total RNA was isolated from the hippocampus using a TRI reagent (Sigma). The extracted RNA was reverse-transcribed using the High-Capacity cDNA Reverse Transcription Kit (Applied Biosystems, Foster City, CA, USA). The mRNA expression was determined by Taqman Gene Expression Assays (Applied Biosystems) using $1 \mu \mathrm{L}$ of cDNA in a reaction of $10 \mu \mathrm{L}$. The assay IDs were Rn02396759_m1 for rat c-Fos and Rn00667869_m1 for $\beta$-actin. The fold change in the gene expression was determined by the $2^{-\Delta \Delta \mathrm{Ct}}$ method [69]. 


\section{Conclusions}

Analyzing the antiepileptogenic efficacy of AEDs and other agents, it is possible to delineate the most effective targets and targets playing a much lesser role in this regard. Considering AEDs, there are examples of their antiepileptogenic potential.

As regards the mechanisms of action of AEDs, they interact with the main three targets in the central nervous system: voltage-gated sodium or calcium channels, $\mathrm{GABA}_{\mathrm{A}}$ receptor-mediated inhibition and glutamate-induced excitatory events $[8,13]$. The $\mathrm{GABA}_{\mathrm{A}}$ receptor may, in part, appear to be a recommendable target for antiepileptogenesis, because diazepam (a positive $\mathrm{GABA}_{\mathrm{A}}$ receptor modulator) at a single but high dose of $20 \mathrm{mg} / \mathrm{kg}$ very potently inhibited spontaneous seizure activity following status epilepticus induced in rats by electrical stimulation of the amygdala [74]. Valproate, an AED with multiple mechanisms of action, is also closely associated with GABA-ergic neurotransmission in that it increases GABA turnover in brain regions responsible for seizure generation and propagation [75]. However, only some, but not all, experimental data confirmed the antiepileptogenic properties of this drug (see above). Apparently, a number of factors (a method of status epilepticus induction, administration time and dosing) may influence its final antiepileptogenic effect. After all, phenobarbital, positively modulating $\mathrm{GABA}_{\mathrm{A}}$ receptor-mediated inhibition [13], was shown to possess a seizure modifying the activity in rats after status epilepticus produced by lithium-pilocarpine [11]. However, phenobarbital was shown ineffective in animals in another model of status epilepticus, even when combined with levetiracetam [38].

A number of antioxidants have shown antiepileptogenic potential, so the question arises whether targeting the mechanism of the antioxidative defense might be of importance for the inhibition of epileptogenesis. Resveratrol was shown to exert diverse antioxidative effects-for instance, it reduces the production of free radicals and increases the activity of antioxidative enzymes: superoxide dismutase, catalase and glutathione peroxidase [41]. Certainly, its antioxidative properties are closely related to its anti-inflammatory activity, because free radicals have been found to promote inflammation [76]. Actually, resveratrol is an efficient suppressor of microglia-induced neuroinflammation and subsequent neuronal damage of inflammatory origin. Possibly, its anti-inflammatory activity may result from its direct inhibitory effect upon the synthesis of anti-inflammatory factors [41]. Sulforaphane was also effective in epileptogenesis inhibition, and its antioxidative activity is associated with Nrf2, which promotes the transcription of a number of antioxidant response genes [46]. Actually, sulforaphane has been shown to increase the expression of Nrf2 in the nucleus in vivo, and by the way, it also reduces the secretion of proinflammatory cytokines, which speaks to its direct interaction with nuclear factor kappa B [77]. N-acetylcysteine, exerting antiepileptogenic activity in combination with sulforaphane, is a direct antioxidant [78]. It is of importance that there are other examples of already approved drugs that share, among other properties, an antioxidative potential—for instance, minocycline [35]. This drug also exhibits an anti-inflammatory activity that is also shared by some antioxidative agents (resveratrol and sulforaphane). Curcumin is also a good example of an antioxidant and anti-inflammatory agents, as it can also act as an inflammasome silencer [79]. Summing up, the antiepileptogenic effects exerted by antioxidative compounds/drugs indicate that free radicals and antioxidant enzymes may become encouraging targets for antiepileptogenesis.

The anti-inflammatory drug celecoxib (an inhibitor of the cyclooxygenase 2 and HMGB1/TLR-4 pathways) has been documented to significantly reduce the remote consequences of status epilepticus in rats. These are recurrent spontaneous seizures, hippocampal neurodegeneration with aberrant neurogenesis/gliogenesis [31]. The beneficial antiepileptogenic activity of celecoxib may be interpreted in terms of targeting the inflammatory pathways.

A growing body of evidence seems to suggest that the m-TOR complex may be involved in an epilepsy-modifying effect. This may be attributed to the fact that rapamycin in some post-status epilepticus models of epileptogenesis exerted a positive activity [27,28]. However, in some experimental approaches, rapamycin was completely inactive $[29,30]$. 
Probably, these discrepancies may be partially explained by the pharmacokinetics of the drug. According to Abs et al. [80], rapamycin evidently accumulates in the rat brain following its withdrawal, with still almost $50 \%$ of the drug concentration observed during continuous rapamycin administration. Thus, it is quite possible that the drug itself may be present in the brain when spontaneous seizure activity starts. The ineffectiveness of another antagonist of two mTOR pathways, PQR620 [48], speaks rather against the involvement of these pathways in epileptogenesis inhibition.

The question arises whether the T-type calcium channel may be considered as a target for antiepileptogenesis. Indeed, the results by Casillas-Espinosa et al. [49] seemed to support such a possibility, as the potent antagonist of this channel, Z944, proved very effective in a post-status epilepticus model. Furthermore, this antagonist also very distinctly inhibited the progression of amygdala kindling in rats. Only one out of seven rats was fully kindled [81]. Interestingly, ethosuximide (also a T-type calcium channel antagonist [13]) was totally inactive in this respect-all the rats pretreated with this AED were fully kindled [81]. Perhaps the interaction mode of Z944 and ethosuximide with T-type calcium channels may vary, which can account for the completely different effects of either drug on epileptogenesis. A study by Tringham et al. [82] indicated that there were obvious differences in the mechanisms of antiseizure action of these drugs against thalamic burst firing.

A number of microRNAs may differ in their expression in patients with neurologic diseases, and a good example is microRNA-129-2-3p, which was found elevated both in cortical tissue and the plasma of patients with temporal lobe epilepsy [83]. Recently, the antagomir-induced inhibition of microRNA-129-2-3p has been documented to efficiently block the downregulation of the gabra1 gene, which encodes receptor subunit $\alpha_{1}$ of the $\mathrm{GABA}_{\mathrm{A}}$ receptor complex both in rat primary hippocampal neurons and in rats with kainate-induced seizure activity [84]. Additionally, the silencing of microRNA-134 in mice surviving intra-amygdalar kainate-induced status epilepticus provided distinct neuroprotection and suppressed spontaneous seizure activity recorded between weeks 3 and 4 and 7 and 8 post-status epilepticus. The suppression of spontaneous seizure activity might be, according to the authors, dependent on the reduction by antagomir- 134 of the hippocampal $\mathrm{CA}_{3}$ dendritic spine density [85]. Moreover, a clear-cut antiepileptogenic effect was shown above for the antagomir targeting microRNA-134 [51] after its peripheral administration. The systemic effectiveness of this compound was possible because of the blood/brain barrier disruption by kainate-induced status epilepticus [51].

Regarding c-Fos, it appears reasonable to propose an experimental antiepileptic therapy based on its extending persistence in the brain. Attempts towards this end could make use of one (or both) of the following two mechanisms:

Stimulus-induced c-Fos expression in the brain is prompted by an enhanced acetylation of histone H4 [86,87]. A wide spectrum histone deacetylase (HDAC) inhibitor, sodium butyrate, abrogated c-Fos accumulation in the resting brain [87] and attenuated epileptogenesis in the rat kindling model of TLE [88]. Moreover, an in vitro study revealed HDAC inhibition to be a common feature of three different AEDs: valproate, topiramate and levetiracetam [89], suggesting the possibility that the therapeutic effects of these drugs may be partly mediated by inhibition of c-Fos. Therefore, HDAC inhibitors specifically designed to target $\mathrm{H} 4$ may in the future become attractive AEDs. It has recently been postulated that HDAC inhibitors may alleviate epileptogenesis also by interacting with non-histone targets [90].

Elimination of c-Fos upon prolonged stimulation of pertinent brain regions in disease models other than epilepsy is associated with its increased interaction with a transcription factor $\Delta \mathrm{FosB}$, which is activated in a chronic but not in the early-stage poststimulation [91,92]. If this mechanism applies to epilepsy, attempts at inactivating $\Delta$ FosB in due course may become a plausible therapeutic option as well.

As already pointed out above, DNA methylation or TrkB receptor-mediated events may be also considered as potential targets for the inhibition of epileptogenesis. Some clini- 
cal studies on the inhibition of epileptogenesis were conducted in patients suffering from head traumas, however, the preventive use of AEDs failed to stop posttraumatic epilepsy (for review, [2]). Specifically, carbamazepine, phenobarbital, and phenytoin were not effective at all and valproate even tended to elevate mortality in patients with posttraumatic epilepsy. There is some hope with levetiracetam which exerted a slight, albeit statistically insignificant preventive activity in this respect, [2]. Some newer clinical data on this issue are less optimistic [93]. So far, apart from AEDs, only biperiden (an anti-parkinsonian anticholinergic drug) has been evaluated in patients after brain injury in a small phase II safety assessment, prior to a double blind, randomized, placebo-controlled trial. The initial assessment confirmed its safety in patients with brain injuries and preliminary data seem to indicate that the drug seems to reduce the incidence of post-traumatic epilepsy [94]. Interestingly, biperiden has shown clear-cut antiepileptogenic properties in post-SE (induced by pilocarpine in rats) model of recurrent spontaneous convulsions [95]. Other non-antiepileptic drugs shown above, have not been tested yet in clinical trials aimed at counteracting epileptogenesis.

All the above discussed ligands considered for use as molecular targets for antiepileptogenesis are listed in Table 1. While each of them bears a clinical antiepileptogenic potential, its practical applicability can only be verified in appropriate clinical trials. Whilst patients with brain traumas may be easily recruited for such trials, patients with presumed epileptogenesis following other initial insults would have to be checked with reliable markers for epileptogenesis. Apart from already mentioned EEG markers [10], a possibility exists that also miRNAs may become reliable markers for the process of epileptogenesis or chronic epilepsy [96] and according to the here presented data-c-Fos may be also taken into consideration in this regard. 
Table 1. Anti-epileptogenic potential of various drugs and agents.

\begin{tabular}{|c|c|c|c|c|c|c|c|c|c|c|c|c|c|}
\hline \multirow{2}{*}{\multicolumn{2}{|c|}{ Anti-Epileptogenic Compound }} & \multicolumn{7}{|c|}{ Mechanism of Action [13] } & \multirow[b]{2}{*}{$\begin{array}{c}\text { Model of } \\
\text { Epileptogenesis }\end{array}$} & \multirow[b]{2}{*}{ Duration of Treatment } & \multirow[b]{2}{*}{ Dosage } & \multirow[b]{2}{*}{ Effect } & \multirow[b]{2}{*}{$\begin{array}{l}\text { Refer- } \\
\text { ences }\end{array}$} \\
\hline & & $\begin{array}{l}\text { Sodium } \\
\text { Chan- } \\
\text { nel } \\
\text { Block- } \\
\text { ade }\end{array}$ & $\begin{array}{l}\text { Cal- } \\
\text { cium } \\
\text { Ccha- } \\
\text { nnel } \\
\text { Block- } \\
\text { ade }\end{array}$ & $\begin{array}{l}\text { Potas- } \\
\text { sium } \\
\text { Chan- } \\
\text { nel } \\
\text { Acti- } \\
\text { va- } \\
\text { tion }\end{array}$ & $\begin{array}{l}\text { In- } \\
\text { crease } \\
\text { in } \\
\text { GABA } \\
\text { Level }\end{array}$ & $\begin{array}{l}\text { In- } \\
\text { creased } \\
\text { GABA } \\
\text { Trans- } \\
\text { mis- } \\
\text { sion }\end{array}$ & $\begin{array}{l}\text { Inhibi- } \\
\text { tion of } \\
\text { Gluta- } \\
\text { mate } \\
\text { Excita- } \\
\text { tion }\end{array}$ & $\begin{array}{l}\text { Other } \\
\text { Mech- } \\
\text { a- } \\
\text { nisms } \\
\text { of } \\
\text { Ac- } \\
\text { tion }\end{array}$ & & & & & \\
\hline \multirow{4}{*}{$\begin{array}{l}\text { Antiepileptic } \\
\text { drugs }\end{array}$} & Phenobarbital & + & & & + & + & + & + & $\begin{array}{l}\text { Lithium-pilocarpine- } \\
\text { induced status } \\
\text { epilepticus in rats }\end{array}$ & $\begin{array}{c}14 \text { days } \\
\text { Spontaneous seizure } \\
\text { activity was studied for } \\
7 \text { days between } 8 \text { and } \\
9 \text { weeks after status } \\
\text { epilepticus } \\
28 \text { days }\end{array}$ & $\begin{array}{l}15 \mathrm{mg} / \mathrm{kg} / \mathrm{twice} \\
\text { daily i.p. }\end{array}$ & $\begin{array}{l}\text { Reduction in the number of rats } \\
\text { with spontaneous seizure activity; } \\
\text { the median frequency of } \\
\text { convulsions sharply diminished } \\
\text { from } 7.5 \text { to } 1 \text { seizure/week }\end{array}$ & [11] \\
\hline & Levetiracetam & & + & & & + & & + & $\begin{array}{l}\text { Pilocarpine-produced } \\
\text { status epilepticus in } \\
\text { mice }\end{array}$ & $\begin{array}{l}\text { Seizure activity was } \\
\text { assessed in the presence } \\
\text { of levetiracetam within } \\
\text { four weeks after status } \\
\text { epilepticus }\end{array}$ & $\begin{array}{l}500 \mathrm{mg} / \mathrm{kg} / \\
\text { twice daily, p.o. }\end{array}$ & $\begin{array}{l}\text { Reduction the number of } \\
\text { spontaneous seizures and mortality; } \\
\text { Present neuroprotective effect }\end{array}$ & [12] \\
\hline & Eslicarbazepine & + & + & & & & & & $\begin{array}{l}\text { Pilocarpine-produced } \\
\text { status epilepticus in } \\
\text { mice }\end{array}$ & 42 days & $\begin{array}{l}150 \mathrm{and} \\
300 \mathrm{mg} / \mathrm{kg} / \\
\text { once daily, i.p. }\end{array}$ & $\begin{array}{c}\text { Reduction spontaneous seizure } \\
\text { activity; } \\
\text { The mossy fiber sprouting was } \\
\text { considerably inhibited; } \\
\text { Inhibitor of epileptogenesis }\end{array}$ & [14] \\
\hline & Ethosuximide & & + & & & & & & $\begin{array}{l}\text { Lithium-pilocarpine- } \\
\text { induced status } \\
\text { epilepticus in rats }\end{array}$ & 7 days & $\begin{array}{c}25 \text { and } \\
50 \mathrm{mg} / \mathrm{kg} / \text { daily } \\
\text { AED given i.p. } \\
24 \text { hours after } \\
\text { status epilepticus }\end{array}$ & No effect & [17] \\
\hline
\end{tabular}


Table 1. Cont.

\section{Mechanism of Action [13]}

\begin{tabular}{|c|c|c|c|c|c|c|}
\hline Inti-Epileptogenic Compound & $\begin{array}{l}\text { Sodium } \\
\text { Chan- } \\
\text { nel } \\
\text { Block- } \\
\text { ade }\end{array}$ & $\begin{array}{l}\text { Cal- } \\
\text { cium } \\
\text { Ccha- } \\
\text { nnel } \\
\text { Block- } \\
\text { ade }\end{array}$ & $\begin{array}{l}\text { Potas- } \\
\text { sium } \\
\text { Chan- } \\
\text { nel } \\
\text { Acti- } \\
\text { va- } \\
\text { tion }\end{array}$ & $\begin{array}{l}\text { In- } \\
\text { crease } \\
\text { in } \\
\text { GABA } \\
\text { Level }\end{array}$ & $\begin{array}{l}\text { In- } \\
\text { creased } \\
\text { GABA } \\
\text { Trans- } \\
\text { mis- } \\
\text { sion }\end{array}$ & $\begin{array}{c}\text { Inhibi- } \\
\text { tion of } \\
\text { Gluta- } \\
\text { mate } \\
\text { Excita- } \\
\text { tion }\end{array}$ \\
\hline
\end{tabular}

Model of
Epileptogenesis

\section{Duration of
Treatment}

Dosage

Effect

Refer-

Rat model of required
epilepsy in which
sodium deoxycholate,
via a craniotomy
window, was
administered to the
brain surface

7 days

Spontaneous
seizure activity

was evaluated

for 2 weeks

Recording

Losartan

A blocker of angiotensin II type 1 receptors

brain surface

graphic activity
for 110 days

$100 \mathrm{mg} / \mathrm{kg}$ i.p.

Administered 40

Significant reduction of spontaneous

min following
deoxycholate

convulsions, sharp reduction in the

S.c. at $10 \mathrm{mg} / \mathrm{kg}$

2 hours after the

Kainate post-status

epilepticus-induced

epileptogenesis in rats

4 weeks

Spontaneous

onset of status

epilepticus and

was evaluated the $3^{\text {rd }}$ day and

for 3 months

then the animals

ched to

losartan in

Kainate-induced status epilepticus in rats

21 days

$6 \mathrm{mg} / \mathrm{kg}$ every 4 days

Blockade of mTOR complex 1 pathway

$6 \mathrm{mg} / \mathrm{kg} \mathrm{d}$ a

non-AEDs with

Rapamycin

ectrical stimulation of

for a week and

Electrical stimulation of
the rat angular bundle

6 weeks

day for 6 weeks

epileptogenic

$\mathrm{g}$

Pilocarpine-induced

status epilepticus in mice following statu
epilepticus

2 months

$10 \mathrm{mg} / \mathrm{kg}$

$3 \mathrm{mg} / \mathrm{kg}$
Increased the latency to the onset of eizures and provided distinct neuroprotection to CA1 hippoctinct subfield, extended the latency time to the development of fully kindled seizures, neuroprotection being less expressed, in behavioral tests-considerably less deficits Some seizure parameters (threshold for after discharge induction, after discharge duration or seizure severity in fully Considerable reduction in the number of spontaneous convulsions

Totally inhibited the occurrence of spontaneous seizure activity in $25 \%$ of , reduction of seizure activity

No difference in seizure frequency, Mossy fiber sprouting and dentate gyrus hypertrophy were suppressed Mossy fiber sprouting was reduced, hypertrophy of the dentate gyrus was decreased, generation of ectopic granule proliferation were observed 
Table 1. Cont.

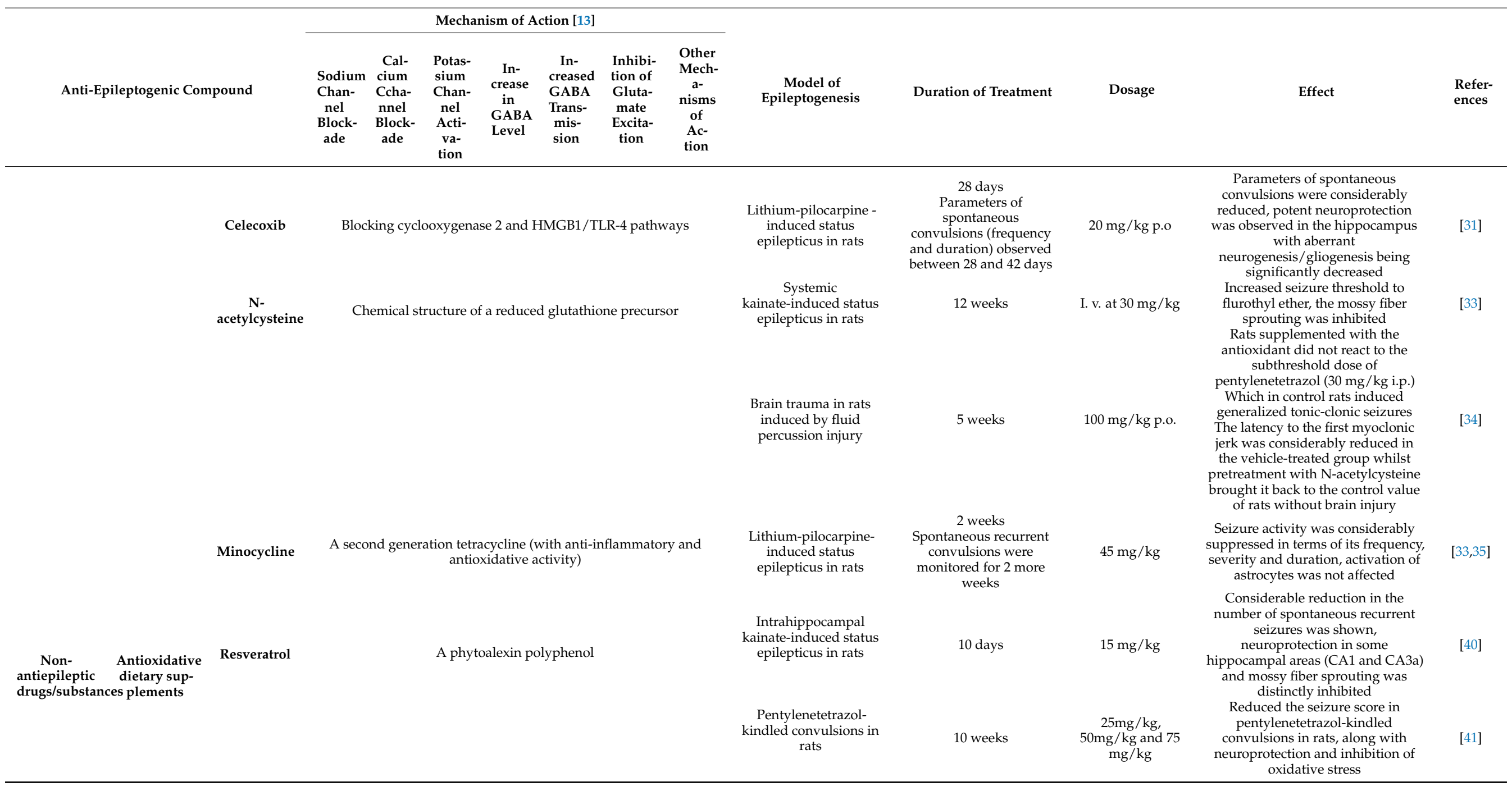


Table 1. Cont.

Mechanism of Action [13]

\begin{tabular}{|c|c|c|c|c|c|c|}
\hline $\begin{array}{l}\text { Sodiun } \\
\text { Chan- } \\
\text { nel } \\
\text { Block- }\end{array}$ & $\begin{array}{l}\text { Cal- } \\
\text { ncium } \\
\text { Ccha- } \\
\text { n- } \\
\text { nel }\end{array}$ & $\begin{array}{l}\text { Potas- } \\
\text { sium } \\
\text { Chan- } \\
\text { nel } \\
\text { Acti- }\end{array}$ & $\begin{array}{l}\text { In- } \\
\text { crease } \\
\text { in } \\
\text { GABA } \\
\text { Level }\end{array}$ & $\begin{array}{l}\text { In- } \\
\text { creased } \\
\text { GABA } \\
\text { Trans- } \\
\text { mis- }\end{array}$ & $\begin{array}{c}\text { Inhibi- } \\
\text { d tion of } \\
\text { Gluta- } \\
\text { mate } \\
\text { Excita- }\end{array}$ & $\begin{array}{l}\text { Other } \\
\text { Mecha- } \\
\text { nisms } \\
\text { of } \\
\text { Action }\end{array}$ \\
\hline ade & $\begin{array}{l}\text { Block- } \\
\text { ade }\end{array}$ & $\begin{array}{c}\text { va- } \\
\text { tion }\end{array}$ & & & tion & \\
\hline
\end{tabular}

Anti-Epileptogenic Compound

Curcumin

Antioxidant activity, also anti-inflammatory and neuroprotective properties

\section{Post-electrical rat
model for model for
temporal lobe \\ epilepsy}

Model of

pileptogenesis

esis

Duration of Treatment

Dosage

Effect

Refer-

ainate-induced in rats

week

$2 \mu 1$ of $2 \mathrm{~mm}$
curcumin

solution

In vitro activity was not confirmed in hippocampal tissue

Did not prevent the development but

$100 \mathrm{mg} / \mathrm{kg} \quad \begin{gathered}\text { reduced the severity of subsequent } \\ \text { spontaneous convulsions and offered a } \\ \text { significant protection against cognitive }\end{gathered}$

$100 \mathrm{mg} / \mathrm{kg} \quad \begin{aligned} & \text { reduced the severity of subsequent } \\ & \text { spontaneous convulsions and offered a } \\ & \text { significant protection against cognitive }\end{aligned}$ impairmen

An activator of the transcription factor (nuclear factor erythuid 2-related factor 2; Nrf2) responsible for the

Sulforaphane number of cytoprotective genes

Examples of compounds anti-epileptogenic potential
PQR530

PQR530
Z-944

Adenosine

Antagomir
PQR620

PQR530

Blockade of mTOR pathways

An inhibitor of the phosphoinositide-3 kinase (PI3K)-AKT/mTOR pathway)

Z-944
Induced status epilepticus in stimulation of stimulation of
the ventral 7 days +7 days

hippocampus

Measured betwe 2 ression

Sulforaphane (5 mg/kg i.p.)

acetylcysteine
$(500 \mathrm{mg} / \mathrm{kg}$

i.p.) For seven
days followed

by
sulforaphane

sulforaphane

alone for

Status

epilepticus

intrahippocamal

kainate

Kainate-induced

and subsequent

epileptogenesis
in rats

\section{2 weeks
The seizure evaluth}

The seizure evaluation

4 weeks

The animals were tested for the occurrence of spontaneous recurrent
convulsions for the next 2 weeks another 7 days

At dong the

blocking th
mTOR

signaling

$60 \mathrm{mg} / \mathrm{kg}$

daily via

continuous

subcutaneous

infusion begun 6 weeks after the drug
Inhibited epileptogenesis progression which was reflected by the significant reduction in the frequency of spontaneous seizures evaluated 5 months after status epilepticus, Neurodegeneration was considerably less expressed and they performed better in behavioral tests for cognition

No protective effect of the pretreatment with this compound on spontaneous seizure dentate gyrus was recorded

Less intense seizure activity manifested by reduced number of convulsions, significant deficits in spatial learning and memory task as well as distinct depressive-like behavior vs. Animals without status epilepticus influence on granule cell dispersion in the 
Table 1. Cont.

Mechanism of Action [13]

$\begin{array}{lllclcc} & \text { Cal- } & \text { Potas- } & \text { In- } & \text { In- } & \text { Inhibi- } & \text { Other } \\ \text { Anti-Epileptogenic Compound } & \text { Sodiumium } & \text { sium } & \text { cre- } & \text { creased } & \text { tion of } & \text { Mecha- } \\ & \text { Chan- Cha- } & \text { Chan- } & \text { crease } & \text { GABA } & \text { Gluta- } & \text { nisms } \\ & \text { nel nnel } & \text { nel } & \text { in } & \text { Trans- } & \text { mate } & \text { of } \\ & \text { Block- Block- } & \text { Acti- } & \text { GABA } & \text { mis- } & \text { Excita- } & \text { of } \\ & \text { ade ade } & \text { va- } & \text { Level } & \text { mion } & \text { tion } & \text { Action } \\ & & \text { tion } & & & & \end{array}$

Adenosine

Induces hypomethylation of DNA via biochemical interference with the transmethylation pathway

Antagomir

An antisense oligonucleotide which targets microRNA-134 (ANT-134)

1NMMP1

1NMPP1 turns into an active inhibitor after a genetic modification in the trkb (BDNF receptor which is tropomyosin-related kinase B) locus which consists in a substitution of alanine for phenylalanine at residue 616 .

her
of
Action

E

Model of
Epileptogenesis

Duration of Treatment

Dosage

Effect

Refer-

10 days

Spontaneous seizures

were evaluated between

since the induction of

status epilepticus.

2 hours after the induction of status

epilepticus

Intraamygdalar

epilepticus in rats

Amygdala

kainate-induced statu epilepticus in mice

Amygdala-kindled mice 6 days of seizure free period received an electrical stimulus
inducing a seizure

response (Seizure \#1)

and then, after 8 days a second stimulu
(Seizure \#2)
5-6 weeks - measuring spontaneous seizures After 8 weeks post-status epilepticus -
250 ng daily through
silk-based polymer silk-based polymer ventricles

\section{$30 \mathrm{mg} / \mathrm{kg}$, i.p.}

$16.6 \mu \mathrm{g} / \mathrm{g}, 40$ and $60 \mathrm{~min}$ after intra-amygdalar kainate (with diazepam a $10 \mathrm{mg} / \mathrm{kg}$ and lorazepam at $6 \mathrm{mg} / \mathrm{kg}$ ),

respectively, to terminate status epilepticus) and then once daily. Also available in the drinking weeks, 1NMMP1 was$$
\begin{aligned}
& \text { ws, } 1 \text { NMMP1 } \\
& \text { withdrawn. }
\end{aligned}
$$

$16.6 \mu \mathrm{g} / \mathrm{g}$ i.p. After the seizure \#1 every 12 hours up to a total of 5 injections and the mice also had access to the drinking water with the trkb inhibitor (at $25 \mu \mathrm{m}$ ) for 2 days.

Applied after Seizure \#1 at $20 \mathrm{mg} / \mathrm{kg}$ i.p. For a total amygdala-kindled mice
Potently inhibited the increase in seizure frequency per week between 10-13 weeks and completely blocked the further increase in this parameter when valuated between 18-21 weeks, mossy fiber sprouting was

12 weeks podut when studied 12 weeks post status epilepticus totally blocked by a the single injection, reduced astrogliosis was found in the hippocampus

Sharp reduction in the occurrence of spontaneous seizure activity in the long-term period after status epileptics, anxiety-like behavior was ameliorated in genetically modified mice in the light-dark neffective in unmodified animals

In genetically modified mice there was a clear cut prevention of the $50 \%$ increase in electrographic seizure duration, $25 \%$ increase in behavioral seizure duration as well as $75 \%$ increase in duration of ictal and postictal events. Beneficial events were not seen in modified the TrkB inhibitor itself 
Table 1. Cont.

\begin{tabular}{|c|c|c|c|c|c|c|c|c|c|c|c|c|c|}
\hline \multirow{2}{*}{\multicolumn{2}{|c|}{ Anti-Epileptogenic Compound }} & \multicolumn{7}{|c|}{ Mechanism of Action [13] } & \multirow[b]{2}{*}{$\begin{array}{c}\text { Model of } \\
\text { Epileptogenesis }\end{array}$} & \multirow[b]{2}{*}{$\begin{array}{l}\text { Duration of } \\
\text { Treatment }\end{array}$} & \multirow[b]{2}{*}{ Dosage } & \multirow[b]{2}{*}{ Effect } & \multirow[b]{2}{*}{ Reference } \\
\hline & & $\begin{array}{l}\text { Sodium } \\
\text { Chan- } \\
\text { nel } \\
\text { Block- } \\
\text { ade }\end{array}$ & $\begin{array}{l}\text { Cal- } \\
\text { cium } \\
\text { Ccha- } \\
\text { nnel } \\
\text { Block- } \\
\text { ade }\end{array}$ & $\begin{array}{l}\text { Potas- } \\
\text { sium } \\
\text { Chan- } \\
\text { nel } \\
\text { Acti- } \\
\text { va- } \\
\text { tion }\end{array}$ & $\begin{array}{l}\text { In- } \\
\text { crease } \\
\text { in } \\
\text { GABA } \\
\text { Level }\end{array}$ & $\begin{array}{l}\text { In- } \\
\text { creased } \\
\text { GABA } \\
\text { Trans- } \\
\text { mis- } \\
\text { sion }\end{array}$ & $\begin{array}{l}\text { Inhibi- } \\
\text { tion of } \\
\text { Gluta- } \\
\text { mate } \\
\text { Excita- } \\
\text { tion }\end{array}$ & $\begin{array}{l}\text { Other } \\
\text { Mech- } \\
\text { a- } \\
\text { nisms } \\
\text { of } \\
\text { Ac- } \\
\text { tion }\end{array}$ & & & & & \\
\hline \multirow{3}{*}{$\begin{array}{l}\text { Combined } \\
\text { treatments }\end{array}$} & Levetiracetam & + & + & + & + & + & + & + & $\begin{array}{l}\text { Intrahippocampal } \\
\text { kainate-induced status } \\
\text { epilepticus in mice }\end{array}$ & $\begin{array}{l}5 \text { days (latent } \\
\text { period), starting } \\
\text { after } 6 \text { hours } \\
\text { from the status } \\
\text { induction }\end{array}$ & $\begin{array}{l}\text { Levetiracetam } \\
(200 \mathrm{mg} / \mathrm{kg} \text { i.p. })+ \\
\text { topiramate } \\
(30 \mathrm{mg} / \mathrm{kg} \text { i.p. })\end{array}$ & $\begin{array}{l}\text { Reduction the frequency of spontaneous } \\
\text { recurrent electroclinical seizures by } 80 \% \\
\text { when compared to non-treated mice and } \\
\text { generalized seizures (stages } 4 \text { and } 5 \\
\text { according to a Racine scale). } \\
\text { Reduction a number of animals with } \\
\text { spontaneous electroclinical convulsions } \\
\text { (some mice were completely protected); } \\
\text { No effects on electrographic seizure activity, } \\
\text { neurodegeneration or inflammatory reactions }\end{array}$ & {$[54]$} \\
\hline & Levetiracetam & + & + & & + & + & + & + & $\begin{array}{l}\text { Intrahippocamal } \\
\text { kainate-induced status } \\
\text { epilepticus in mice }\end{array}$ & $\begin{array}{l}5 \text { days (latent } \\
\text { period), starting } \\
\text { after } 6 \text { hours } \\
\text { from the status } \\
\text { induction }\end{array}$ & $\begin{array}{c}\text { Phenobarbital, } \\
\text { initiated by a bolus } \\
\text { dose of } 25 \mathrm{mg} / \mathrm{kg} \\
\text { and then } 3 \text { times } \\
\text { daily at } 15 \mathrm{mg} / \mathrm{kg} \\
\text { i.p.) + } \\
\text { levetiracetam } \\
\text { (200 mg/kg i.p.) }\end{array}$ & $\begin{array}{l}\text { No effect on incidence or frequency of } \\
\text { electroclinical or electrographic seizures }\end{array}$ & {$[54]$} \\
\hline & $\begin{array}{l}\text { Levetiracetam } \\
\text { Atorvastatin } \\
\text { Ceftriaxone }\end{array}$ & A & $\stackrel{+}{+}$ & $\begin{array}{r}\text { umatic } \\
\text { in }\end{array}$ & $\begin{array}{l}\text { wnregul } \\
\text { he brain" }\end{array}$ & $\stackrel{+}{\text { KG-coa re }^{-}}$ & tamate tran & nsport & $\begin{array}{l}\text { Intrahippocamal } \\
\text { kainate-induced status } \\
\text { epilepticus in mice }\end{array}$ & $\begin{array}{l}5 \text { days (latent } \\
\text { period), starting } \\
\text { after } 6 \text { hours } \\
\text { from the status } \\
\text { induction }\end{array}$ & $\begin{array}{l}\text { Levetiracetam } \\
(60 \mathrm{mg} / \mathrm{kg} \text { i.p. })+ \\
\text { atorvastatin } \\
(3 \mathrm{mg} / \mathrm{kg} \text { i.p. })+ \\
\text { ceftriaxone } \\
(60 \mathrm{mg} / \mathrm{kg} \text { i.p. })\end{array}$ & $\begin{array}{l}\text { Reduce the incidence of electroclinical } \\
\text { seizures (by } 100 \% \text { ) and the incidence of } \\
\text { electrographic seizures (by } 60 \% \text { ) as well; } \\
\text { No effect on hippocampal neurodegeneration }\end{array}$ & {$[55]$} \\
\hline
\end{tabular}


Author Contributions: Conceptualization, S.J.C. and J.A., M.J.P., B.M., J.A. and S.J.C. contributed to the writing of this article. Table and reference preparation and editions, B.M., A.W., A.K. and M.C.-K.; writing-review and editing, S.J.C. and J.A.; funding acquisition, J.A. and visualization and execution of c-Fos experiments, M.J.P. All authors have read and agreed to the final version of the manuscript.

Funding: The authors are grateful for the financial support from the National Science Centre (NCN) of Poland (2016/23/B/NZ4/03678) (M.J.P. and J.A.), European Social Fund (ESF) (POWR.03.02.0000-1028/17-00 (M.J.P.) and the Medical University of Lublin for the statutory grant DS/475/21 (S.J.C.).

Institutional Review Board Statement: Animal experiments described in Fig. 1. were conducted according to the guidelines of the Declaration of Helsinki and the national guidelines on animal experimentation, and were approved by the local ethical committee in Warsaw (consent no. 405/2017, 21.11.2017) in accordance with EC Directive 2010/63/EU.

Informed Consent Statement: Not applicable.

Data Availability Statement: Not applicable.

Conflicts of Interest: S.J.C. received financial support from Bayer, GlaxoSmithKline, Janssen, Novartis and Sanofi-Aventis for lecturing. He is also a recipient of an unrestricted grant from GlaxoSmithKline. The remaining authors have no conflicts of interest to disclose.

\section{References}

1. Kwan, P.; Brodie, M.J. Early identification of refractory epilepsy. N. Engl. J. Med. 2000, 342, 314-319. [CrossRef]

2. Miziak, B.; Konarzewska, A.; Ułamek-Kozioł, M.; Dudra-Jastrzebska, M.; Pluta, R.; Czuczwar, S.J. Neuroprotective effects of antiepileptic drugs in epilepsy. Int. J. Mol. Sci. 2020, 21, 2340. [CrossRef] [PubMed]

3. Koepp, M.J.; Årstad, E.; Bankstahl, J.P.; Dedeurwaerdere, S.; Friedman, A.; Potschka, H.; Ravizza, T.; Theodore, W.H.; Baram, T.Z. Neuroinflammation imaging markers for epileptogenesis. Epilepsia 2017, 58 (Suppl. 3), 11-19. [CrossRef] [PubMed]

4. Williams, P.A.; Hellier, J.L.; White, A.M.; Staley, K.J.; Dudek, F.E. Development of spontaneous seizures after experimental status epilepticus: Implications for understanding epileptgenesis. Epilepsia 2007, 48 (Suppl. 5), 157-163. [CrossRef] [PubMed]

5. Łukawski, K.; Andres-Mach, M.; Czuczwar, M.; Łuszczki, J.J.; Kruszyński, K.; Czuczwar, S.J. Mechanisms of epileptogenesis and preclinical approach to antiepileptogenic therapies. Pharmacol. Rep. 2018, 70, 284-293. [CrossRef]

6. Koyama, R. Dentate circuitry as a model to study epileptogenesis. Biol. Pharm. Bull. 2016, 39, 891-896. [CrossRef] [PubMed]

7. Błaszczyk, B.; Miziak, B.; Czuczwar, P.; Wierzchowska-Cioch, E.; Pluta, R.; Czuczwar, S.J. A viewpoint on rational and irrational fixed-drug combinations. Expert Rev. Clin. Pharmacol. 2018, 11, 761-771. [CrossRef]

8. $\quad$ Łukawski, K.; Gryta, P.; Łuszczki, J.; Czuczwar, S.J. Exploring the latest avenues for antiepileptic drug discovery and development. Expert Opin. Drug Discov. 2016, 11, 369-382. [CrossRef]

9. Łukawski, K.; Czuczwar, S.J. Developing precision treatments for epilepsy using patient and animal models. Expert Rev. Neurother. 2020, 1-10. [CrossRef]

10. Patel, A.A.; Jannati, A.; Dhamne, S.C.; Sapuwa, M.; Kalanga, E.; Mazumdar, M.; Birbeck, G.L.; Rotenberg, A. EEG markers predictive of epilepsy risk in pediatric cerebral malaria-A feasibility study. Epilepsy Behav. 2020, 113, 107536. [CrossRef]

11. Brandt, C.; Nozadze, M.; Heuchert, N.; Rattka, M.; Löscher, W. Disease-modifying effects of phenobarbital and the NKCC1 inhibitor bumetanide in the pilocarpine model of temporal lobe epilepsy. J. Neurosci. 2010, 30, 8602-8612. [CrossRef]

12. Itoh, K.; Inamine, M.; Oshima, W.; Kotani, M.; Chiba, Y.; Ueno, M.; Ishihara, Y. Prevention of status epilepticus-induced brain edema and neuronal cell loss by repeated treatment with high-dose levetiracetam. Brain Res. 2015, 1608, 225-234. [CrossRef] [PubMed]

13. Lasoń, W.; Dudra-Jastrzębska, M.; Rejdak, K.; Czuczwar, S.J. Basic mechanisms of antiepileptic drugs and their pharmacokinetic/pharmacodynamic interactions: An update. Pharmacol. Rep. 2011, 63, 271-292. [CrossRef]

14. Doeser, A.; Dickhof, G.; Reitze, M.; Uebachs, M.; Schaub, C.; Pires, N.M.; Bonifácio, M.J.; Soares-da-Silva, P.; Beck, H. Targeting pharmacoresistant epilepsy and epileptogenesis with a dual-purpose antiepileptic drug. Brain 2015, 138, 371-387. [CrossRef] [PubMed]

15. Lee, C.Y.; Fu, W.M.; Chen, C.C.; Su, M.J.; Liou, H.H. Lamotrigine inhibits postsynaptic AMPA receptor and glutamate release in the dentate gyrus. Epilepsia 2008, 49, 888-897. [CrossRef] [PubMed]

16. Wang, J.; Chen, Y.; Wang, Q.; van Luijtelaar, G.; Sun, M. The effects of lamotrigine and ethosuximide on seizure frequency, neuronal loss, and astrogliosis in a model of temporal-lobe epilepsy. Brain Res. 2019, 1712, 1-6. [CrossRef]

17. Fukushima, K.; Hatanaka, K.; Sagane, K.; Ido, K. Inhibitory effect of anti-seizure medications on ionotropic glutamate receptors: Special focus on AMPA receptor subunits. Epilepsy Res. 2020, 167, 106452. [CrossRef] [PubMed] 
18. Bar-Klein, G.; Cacheaux, L.P.; Kamintsky, L.; Prager, O.; Weissberg, I.; Schoknecht, K.; Cheng, P.; Kim, S.Y.; Wood, L.; Heinemann, U.; et al. Losartan prevents acquired epilepsy via TGF- $\beta$ signaling suppression. Ann. Neurol. 2014, 75, 864-875. [CrossRef]

19. McIntosh, T.K.; Noble, L.; Andrews, B.; Faden, A.I. Traumatic brain injury in the rat: Characterization of a midline fluid-percussion model. Cent. Nerv. Syst. Trauma 1987, 4, 119-134. [CrossRef]

20. Krueger, M.; Härtig, W.; Reichenbach, A.; Bechmann, I.; Michalski, D. Blood-brain barrier breakdown after embolic stroke in rats occurs without ultrastructural evidence for disrupting tight junctions. PLoS ONE 2013, 8, e56419. [CrossRef]

21. Valkov, T.; Hristova, J.; Tcherveniakova, T.; Svinarov, D. Blood-brain barrier and intrathecal immune response in patients with neuroinfections. Infez. Med. 2017, 25, 320-325. [PubMed]

22. Cacheaux, L.P.; Ivens, S.; David, Y.; Lakhter, A.J.; Bar-Klein, G.; Shapira, M.; Heinemann, U.; Friedman, A.; Kaufer, D. Transcriptome profiling reveals TGF-beta signaling involvement in epileptogenesis. J. Neurosci. 2009, 29, 8927-8935. [CrossRef] [PubMed]

23. Tchekalarova, J.D.; Ivanova, N.M.; Pechlivanova, D.M.; Atanasova, D.; Lazarov, N.; Kortenska, L.; Mitreva, R.; Lozanov, V.; Stoynev, A. Antiepileptogenic and neuroprotective effects of losartan in kainate model of temporal lobe epilepsy. Pharmacol. Biochem. Behav. 2014, 127, 27-36. [CrossRef]

24. Tchekalarova, J.D.; Ivanova, N.; Atanasova, D.; Pechlivanova, D.M.; Lazarov, N.; Kortenska, L.; Mitreva, R.; Lozanov, V.; Stoynev, A. Long-term treatment with losartan attenuates seizure activity and neuronal damage without affecting behavioral changes in a model of co-morbid hypertension and epilepsy. Cell Mol. Neurobiol. 2016, 36, 927-941. [CrossRef]

25. Nozaki, T.; Ura, H.; Takumi, I.; Kobayashi, S.; Maru, E.; Morita, A. The angiotensin II type I receptor antagonist losartan retards amygdala kindling-induced epileptogenesis. Brain Res. 2018, 1694, 121-128. [CrossRef]

26. Laplante, M.; Sabatini, D.M. mTOR signaling in growth control and disease. Cell 2012, 149, 274-293. [CrossRef] [PubMed]

27. Sosanya, N.M.; Brager, D.H.; Wolfe, S.; Niere, F.; Raab-Graham, K.F. Rapamycin reveals an mTOR-independent repression of Kv1.1 expression during epileptogenesis. Neurobiol. Dis. 2015, 73, 96-105. [CrossRef] [PubMed]

28. Van Vliet, E.A.; Forte, G.; Holtman, L.; den Burger, J.C.; Sinjewel, A.; de Vries, H.E.; Aronica, E.; Gorter, J.A. Inhibition of mammalian target of rapamycin reduces epileptogenesis and blood-brain barrier leakage but not microglia activation. Epilepsia 2012, 53, 1254-1263. [CrossRef]

29. Heng, K.; Haney, M.M.; Buckmaster, P.S. High-dose rapamycin blocks mossy fiber sprouting but not seizures in a mouse model of temporal lobe epilepsy. Epilepsia 2013, 54, 1535-1541. [CrossRef]

30. Buckmaster, P.S.; Lew, F.H. Rapamycin suppresses mossy fiber sprouting but not seizure frequency in a mouse model of temporal lobe epilepsy. J. Neurosci. 2011, 31, 2337-2347. [CrossRef] [PubMed]

31. Jung, K.H.; Chu, K.; Lee, S.T.; Kim, J.; Sinn, D.I.; Kim, J.M.; Park, D.K.; Lee, J.J.; Kim, S.U.; Kim, M.; et al. Cyclooxygenase-2 inhibitor, celecoxib, inhibits the altered hippocampal neurogenesis with attenuation of spontaneous recurrent seizures following pilocarpine-induced status epilepticus. Neurobiol. Dis. 2006, 23, 237-246. [CrossRef] [PubMed]

32. Wei, J.; Pang, C.S.; Han, J.; Yan, H. Effect of orally administered N-acetylcysteine on chronic bronchitis: A Meta-analysis. Adv. Ther. 2019, 36, 3356-3367. [CrossRef] [PubMed]

33. Nomura, S.; Shimakawa, S.; Miyamoto, R.; Fukui, M.; Tamai, H. The involvement of $\mathrm{Na}^{+}, \mathrm{K}^{+}$-ATPase activity and free radical generation in the susceptibility to pentylenetetrazol-induced seizures after experimental traumatic brain injury. Brain Res. 2014, 1590, 65-74. [CrossRef]

34. Silva, L.F.; Hoffmann, M.S.; Rambo, L.M.; Ribeiro, L.R.; Lima, F.D.; Furian, A.F.; Oliveira, M.S.; Fighera, M.R.; Royes, L.F. The involvement of $\mathrm{Na}+, \mathrm{K}+$-ATPase activity and free radical generation in the susceptibility to pentylenetetrazol-induced seizures after experimental traumatic brain injury. J. Neurol. Sci. 2011, 308, 35-40. [CrossRef] [PubMed]

35. Romero-Miguel, D.; Lamanna-Rama, N.; Casquero-Veiga, M.; Gómez-Rangel, V.; Desco, M.; Soto-Montenegro, M.L. Minocycline in neurodegenerative and psychiatric diseases: An update. Eur J Neurol. 2021, 28, 1056-1081. [CrossRef]

36. Wang, N.; Mi, X.; Gu, J.; Wang, W.; Zhang, Y.; Wang, X. Minocycline inhibits brain inflammation and attenuates spontaneous recurrent seizures following pilocarpine-induced status epilepticus. Neuroscience 2015, 87, 144-156. [CrossRef]

37. Russmann, V.; Goc, J.; Boes, K.; Ongerth, T.; Salvamoser, J.D.; Siegl, C.; Potschka, H. Minocycline fails to exert antiepileptogenic effects in a rat status epilepticus model. Eur. J. Pharmacol. 2016, 771, 29-39. [CrossRef]

38. Schidlitzki, A.; Bascuñana, P.; Srivastava, P.K.; Welzel, L.; Twele, F.; Töllner, K.; Käufer, C.; Gericke, B.; Feleke, R.; Meier, M.; et al. Proof-of-concept that network pharmacology is effective to modify development of acquired temporal lobe epilepsy. Neurobiol. Dis. 2020, 134, 104664. [CrossRef]

39. Welzel, L.; Bergin, D.H.; Schidlitzki, A.; Twele, F.; Johne, M.; Klein, P.; Löscher, W. Systematic evaluation of rationally chosen multitargeted drug combinations: A combination of low doses of levetiracetam, atorvastatin and ceftriaxone exerts antiepileptogenic effects in a mouse model of acquired epilepsy. Neurobiol. Dis. 2021, 149, 105227. [CrossRef] [PubMed]

40. Borowicz-Reutt, K.K.; Czuczwar, S.J. Role of oxidative stress in epileptogenesis and potential implications for therapy. Pharmacol. Rep. 2020, 72, 1218-1226. [CrossRef] [PubMed]

41. Meng, T.; Xiao, D.; Muhammed, A.; Deng, J.; Chen, L.; He, J. Anti-inflammatory action and mechanisms of resveratrol. Molecules 2021, 26, 229. [CrossRef] [PubMed]

42. Wu, Z.; Xu, Q.; Zhang, L.; Kong, D.; Ma, R.; Wang, L. Protective effect of resveratrol against kainate-induced temporal lobe epilepsy in rats. Neurochem. Res. 2009, 34, 1393-1400. [CrossRef] [PubMed] 
43. Saha, L.; Chakrabarti, A. Understanding the anti-kindling role and its mechanism of resveratrol in pentylenetetrazole inducedkindling in a rat model. Pharmacol. Biochem. Behav. 2014, 120, 57-64. [CrossRef]

44. Drion, C.M.; van Scheppingen, J.; Arena, A.; Geijtenbeek, K.W.; Kooijman, L.; van Vliet, E.A.; Aronica, E.; Gorter, J.A. Effects of rapamycin and curcumin on inflammation and oxidative stress in vitro and in vivo - in search of potential anti-epileptogenic strategies for temporal lobe epilepsy. J. Neuroinflamm. 2018, 15, 212. [CrossRef] [PubMed]

45. Jiang, Z.; Guo, M.; Shi, C.; Wang, H.; Yao, L.; Liu, L.; Xie, C.; Pu, S.; LaChaud, G.; Shen, J.; et al. Protection against cognitive impairment and modification of epileptogenesis with curcumin in a post-status epilepticus model of temporal lobe epilepsy. Neuroscience 2015, 310, 362-371. [CrossRef] [PubMed]

46. Houghton, C.A.; Fassett, R.G.; Coombes, J.S. Sulforaphane: Translational research from laboratory bench to clinic. Nutr. Rev. 2013, 71, 709-726. [CrossRef]

47. Pauletti, A.; Terrone, G.; Shekh-Ahmad, T.; Salamone, A.; Ravizza, T.; Rizzi, M.; Pastore, A.; Pascente, R.; Liang, L.P.; Villa, B.R.; et al. Targeting oxidative stress improves disease outcomes in a rat model of acquired epilepsy. Brain 2019, 142, e39. [CrossRef]

48. Gericke, B.; Brandt, C.; Theilmann, W.; Welzel, L.; Schidlitzki, A.; Twele, F.; Kaczmarek, E.; Anjum, M.; Hillmann, P.; Löscher, W. Selective inhibition of $\mathrm{mTORC} 1 / 2$ or PI3K/mTORC1/2 signaling does not prevent or modify epilepsy in the intrahippocampal kainate mouse model. Neuropharmacology 2020, 162, 107817. [CrossRef]

49. Casillas-Espinosa, P.M.; Shultz, S.R.; Braine, E.L.; Jones, N.C.; Snutch, T.P.; Powell, K.L.; O’Brien, T.J. Disease-modifying effects of a novel T-type calcium channel antagonist, Z944, in a model of temporal lobe epilepsy. Prog. Neurobiol. 2019, $182,101677$. [CrossRef]

50. Williams-Karnesky, R.L.; Sandau, U.S.; Lusardi, T.A.; Lytle, N.K.; Farrell, J.M.; Pritchard, E.M.; Kaplan, D.L.; Boison, D. Epigenetic changes induced by adenosine augmentation therapy prevent epileptogenesis. J. Clin. Investig. 2013, 123, 3552-3563. [CrossRef]

51. Reschke, C.R.; Silva, L.F.A.; Vangoor, V.R.; Rosso, M.; David, B.; Cavanagh, B.L.; Connolly, N.M.C.; Brennan, G.P.; Sanz-Rodriguez, A.; Mooney, C.; et al. Systemic delivery of antagomirs during blood-brain barrier disruption is diseasemodifying in experimental epilepsy. Mol. Ther. 2021, 29, 2041-2052. [CrossRef] [PubMed]

52. Yamada, K.; Nabeshima, T. Brain-derived neurotrophic factor/TrkB signaling in memory processes. J. Pharmacol. Sci. 2003, 91, 267-270. [CrossRef]

53. Binder, D.K.; Routbort, M.J.; McNamara, J.O. Immunohistochemical evidence of seizure-induced activation of trk receptors in the mossy fiber pathway of adult rat hippocampus. J. Neurosci. 1999, 19, 4616-4626. [CrossRef] [PubMed]

54. Liu, G.; Gu, B.; He, X.-P.; Joshi, R.B.; Wackerle, H.D.; Rodriguiz, R.M.; Wetsel, W.C.; McNamra, J.O. Transient inhibition of TrkB kinase after status epilepticus prevents development of temporal lobe epilepsy. Neuron 2013, 79, 31-38. [CrossRef]

55. Krishnamurthy, K.; Huang, Y.Z.; Harward, S.C.; Sharma, K.K.; Tamayo, D.L.; McNamara, J.O. Regression of epileptogenesis by inhibiting tropomyosin kinase B signaling following a seizure. Ann. Neurol. 2019, 86, 939-950. [CrossRef] [PubMed]

56. Sheng, M.; Greenberg, M.E. The regulation and function of c-fos and other immediate early genes in the nervous system. Neuron 1990, 4, 477-485. [CrossRef]

57. Kovács, K.J. c-Fos as a transcription factor: A stressful (re)view from a functional map. Neurochem. Int. 1998, 33, 287-297. [CrossRef]

58. Calais, J.B.; Valvassori, S.S.; Resende, W.R.; Feier, G.; Athié, M.C.P.; Ribeiro, S.; Gattaz, W.F.; Quevedo, J.; Ojopi, E.B. Long-term decrease in immediate early gene expression after electroconvulsive seizures. J. Neural Transm. 2013, 120, 259-266. [CrossRef]

59. Dyrvig, M.; Christiansen, S.H.; Woldbye, D.P.D.; Lichota, J. Temporal gene expression profile after acute electroconvulsive stimulation in the rat. Gene 2014, 539, 8-14. [CrossRef]

60. Pennypacker, K.R.; Thai, L.; Hong, J.S.; McMillian, M.K. Prolonged expression of AP-1 transcription factors in the rat hippocampus after systemic kainate treatment. J. Neurosci. 1994, 14, 3998-4006. [CrossRef]

61. Willoughby, J.O.; Mackenzie, L.; Medvedev, A.; Hiscock, J.J. Fos induction following systemic kainic acid: Early expression in hippocampus and later widespread expression correlated with seizure. Neuroscience 1997, 77, 379-392. [CrossRef]

62. Dubé, C.; André, V.; Covolan, L.; Ferrandon, A.; Marescaux, C.; Nehlig, A. C-fos, Jun D and HSP72 immunoreactivity, and neuronal injury following lithium-pilocarpine induced status epilepticus in immature and adult rats. Mol. Brain Res. 1998, 63, 139-154. [CrossRef]

63. Motte, J.; Fernandes, M.J.D.S.; Baram, T.Z.; Nehlig, A. Spatial and temporal evolution of neuronal activation, stress and injury in lithium-pilocarpine seizures in adult rats. Brain Res. 1998, 793, 61-72. [CrossRef]

64. Baraban, S.C.; Taylor, M.R.; Castro, P.A.; Baier, H. Pentylenetetrazole induced changes in zebrafish behavior, neural activity and c-fos expression. Neuroscience 2005, 131, 759-768. [CrossRef]

65. Szyndler, J.; Maciejak, P.; Turzyńska, D.; Sobolewska, A.; Taracha, E.; Skórzewska, A.; Lehner, M.; Bidziński, A.; Hamed, A.; Wisłowska-Stanek, A.; et al. Mapping of c-Fos expression in the rat brain during the evolution of pentylenetetrazol-kindled seizures. Epilepsy Behav. 2009, 16, 216-224. [CrossRef]

66. Barros, V.N.; Mundim, M.; Galindo, L.T.; Bittencourt, S.; Porcionatto, M.; Mello, L.E. The pattern of c-Fos expression and its refractory period in the brain of rats and monkeys. Front. Cell. Neurosci. 2015, 9, 1-8. [CrossRef]

67. Schlabitz, S.; Monni, L.; Ragot, A.; Dipper-Wawra, M.; Onken, J.; Holtkamp, M.; Fidzinski, P. Spatiotemporal Correlation of Epileptiform Activity and Gene Expression in vitro. Front. Mol. Neurosci. 2021, 14, 1-17. [CrossRef] [PubMed] 
68. Pawlik, M.J.; Obara-Michlewska, M.; Popek, M.P.; Czarnecka, A.M.; Czuczwar, S.J.; Łuszczki, J.; Kołodziej, M.; Acewicz, A.; Wierzba-Bobrowicz, T.; Albrecht, J. Pretreatment with a glutamine synthetase inhibitor MSO delays the onset of initial seizures induced by pilocarpine in juvenile rats. Brain Res. 2021, 1753, 147253. [CrossRef]

69. Livak, K.J.; Schmittgen, T.D. Analysis of relative gene expression data using real-time quantitative PCR and the 2- $\Delta \Delta C T$ method. Methods 2001, 25, 402-408. [CrossRef]

70. Mercante, B.; Enrico, P.; Floris, G.; Quartu, M.; Boi, M.; Serra, M.P.; Follesa, P.; Deriu, F. Trigeminal nerve stimulation induces Fos immunoreactivity in selected brain regions, increases hippocampal cell proliferation and reduces seizure severity in rats. Neuroscience 2017, 361, 69-80. [CrossRef]

71. Fabene, P.F.; Andrioli, A.; Priel, M.R.; Cavalheiro, E.A.; Bentivoglio, M. Fos induction and persistence, neurodegeneration, and interneuron activation in the hippocampus of epilepsy-resistant versus epilepsy-prone rats after pilocarpine-induced seizures. Hippocampus 2004, 14, 895-907. [CrossRef]

72. Keezer, M.R.; Sisodiya, S.M.; Sander, J.W. Comorbidities of epilepsy: Current concepts and future perspectives. Lancet Neurol. 2016, 15, 106-115. [CrossRef]

73. Ives-Deliperi, V.; Butler, J.T. Mechanisms of cognitive impairment in temporal lobe epilepsy: A systematic review of resting-state functional connectivity studies. Epilepsy Behav. 2021, 115, 107686. [CrossRef] [PubMed]

74. Pitkänen, A.; Kharatishvili, I.; Narkilahti, S.; Lukasiuk, K.; Nissinen, J. Administration of diazepam during status epilepticus reduces development and severity of epilepsy in rat. Epilepsy Res. 2005, 63, 27-42. [CrossRef]

75. Löscher, W. Basic pharmacology of valproate: A review after 35 years of clinical use for the treatment of epilepsy. CNS Drugs 2002, 16, 669-694. [CrossRef] [PubMed]

76. Reuter, S.; Gupta, S.C.; Chaturvedi, M.M.; Aggarwal, B.B. Oxidative stress, inflammation, and cancer: How are they linked? Free Radic. Biol. Med. 2010, 49, 1603-1616. [CrossRef] [PubMed]

77. Santín-Márquez, R.; Alarcón-Aguilar, A.; López-Diazguerrero, N.E.; Chondrogianni, N.; Königsberg, M. Sulforaphane - role in aging and neurodegeneration. Geroscience 2019, 41, 655-670. [CrossRef] [PubMed]

78. Aldini, G.; Altomare, A.; Baron, G.; Vistoli, G.; Carini, M.; Borsani, L.; Sergio, F. N-Acetylcysteine as an antioxidant and disulphide breaking agent: The reasons why. Free Radic. Res. 2018, 52, 751-762. [CrossRef] [PubMed]

79. Hasanzadeh, S.; Read, M.I.; Bland, A.R.; Majeed, M.; Jamialahmadi, T.; Sahebkar, A. Curcumin: An inflammasome silencer. Pharmacol. Res. 2020, 159, 104921. [CrossRef]

80. Abs, E.; Goorden, S.M.I.; Schreiber, J.; Overwater, I.E.; Hoogeveen-Westerveld, M.; Bruinsma, C.F.; Aganović, E.; Borgesius, N.Z.; Nellist, M.; Elgersma, Y. TORC1-dependent epilepsy caused by acute biallelic Tsc1 deletion in adult mice. Ann. Neurol. 2013, 74, 569-579. [CrossRef]

81. Casillas-Espinosa, P.M.; Hicks, A.; Jeffreys, A.; Snutch, T.P.; O’Brien, T.J.; Powell, K.L. Z944, a novel selective T-type calcium channel antagonist delays the progression of seizures in the amygdala kindling model. PLoS ONE 2015, 10, $\mathrm{e} 0130012$.

82. Tringham, E.; Powell, K.L.; Cain, S.M.; Kuplast, K.; Mezeyova, J.; Weerapura, M.; Eduljee, C.; Jiang, X.; Smith, P.; Morrison, J.L.; et al. T-type calcium channel blockers that attenuate thalamic burst firing and suppress absence seizures. Sci. Transl. Med. 2012, 4, 121ra19. [CrossRef]

83. Sun, Y.; Wang, X.; Wang, Z.; Zhang, Y.; Che, N.; Luo, X.; Tan, Z.; Sun, X.; Li, X.; Yang, K.; et al. Expression of microRNA-129-2-3p and microRNA-935 in plasma and brain tissue of human refractory epilepsy. Epilepsy Res. 2016, 127, 276-283. [CrossRef]

84. Wang, G.Y.; Luan, Z.L.; Che, N.W.; Yan, D.B.; Sun, X.W.; Zhang, C.; Yin, J. Inhibition of microRNA-129-2-3p protects against refractory temporal lobe epilepsy by regulating GABRA1. Brain Behav. 2021, e02195. [CrossRef]

85. Jimenez-Mateos, E.M.; Engel, T.; Merino-Serrais, P.; McKiernan, R.C.; Tanaka, K.; Mouri, G.; Sano, T.; O'Tuathaigh, C.; Waddington, J.L.; Prenter, S.; et al. Silencing microRNA-134 produces neuroprotective and prolonged seizure-suppressive effects. Nat. Med. 2012, 18, 1087-1094. [CrossRef] [PubMed]

86. Tsankova, N.M.; Kumar, A.; Nestler, E.J. Histone modifications at gene promoter regions in rat hippocampus after acute and chronic electroconvulsive seizures. J. Neurosci. 2004, 24, 5603-5610. [CrossRef]

87. Maejima, H.; Kitahara, M.; Takamatsu, Y.; Mani, H.; Inoue, T. Effects of exercise and pharmacological inhibition of histone deacetylases (HDACs) on epigenetic regulations and gene expressions crucial for neuronal plasticity in the motor cortex. Brain Res. 2021, 1751, 147191. [CrossRef]

88. Reddy, S.D.; Clossen, B.L.; Reddy, D.S. Epigenetic histone deacetylation inhibition prevents the development and persistence of temporal lobe epilepsy. J. Pharmacol. Exp. Ther. 2018, 364, 97-109. [CrossRef]

89. Eyal, S.; Yagen, B.; Sobol, E.; Altschuler, Y.; Shmuel, M.; Bialer, M. The activity of antiepileptic drugs as histone deacetylase inhibitors. Epilepsia 2004, 45, 737-744. [CrossRef] [PubMed]

90. Kumar, S.; Attrish, D.; Srivastava, A.; Banerjee, J.; Tripathi, M.; Chandra, P.S.; Dixit, A.B. Non-histone substrates of histone deacetylases as potential therapeutic targets in epilepsy. Expert Opin. Ther. Targets 2021, 25, 75-85. [CrossRef]

91. Renthal, W.; Carle, T.L.; Maze, I.; Covington, H.E.; Truong, H.T.; Alibhai, I.; Kumar, A.; Montgomery, R.L.; Olson, E.N.; Nestler, E.J. $\triangle$ FosB mediates epigenetic desensitization of the c-fos gene after chronic amphetamine exposure. J. Neurosci. 2008, 28, 7344-7349. [CrossRef] [PubMed]

92. Corbett, B.F.; You, J.C.; Zhang, X.; Pyfer, M.S.; Tosi, U.; Iascone, D.M.; Petrof, I.; Hazra, A.; Fu, C.H.; Stephens, G.S.; et al. $\Delta$ FosB regulates gene expression and cognitive dysfunction in a mouse model of Alzheimer's disease. Cell Rep. 2017, 20, 344-355. [CrossRef] [PubMed] 
93. Pingue, V.; Mele, C.; Nardone, A. Post-traumatic seizures and antiepileptic therapy as predictors of the functional outcome in patients with traumatic brain injury. Sci. Rep. 2021, 11, 4708. [CrossRef]

94. Benassi, S.K.; Alves, J.G.S.M.; Guidoreni, C.G.; Massant, C.G.; Queiroz, C.M.; Garrido-Sanabria, E.; Loduca, R.D.S.; Susemihl, M.A.; Paiva, W.S.; de Andrade, A.F.; et al. Two decades of research towards a potential first anti-epileptic drug. Seizure 2021, 90, 99-109. [CrossRef]

95. Bittencourt, S.; Ferrazoli, E.; Valente, M.F.; Romariz, S.; Janisset, N.R.L.L.; Macedo, C.E.; Antonio, B.B.; Barros, V.; Mundim, M.; Porcionatto, M.; et al. Modification of the natural progression of epileptogenesis by means of biperiden in the pilocarpine model of epilepsy. Epilepsy Res. 2017, 138, 88-97. [CrossRef]

96. Brindley, E.; Hill, T.D.M.; Henshall, D.C. MicroRNAs as iomarkers and treatment targets in status epilepticus. Epilepsy Behav. 2019, 101, 10672. [CrossRef] 